Article

\title{
Fingerprinting Suspended Sediment Sources in an Urbanized Watershed
}

\author{
Kritika Malhotra ${ }^{1}$, Jasmeet Lamba ${ }^{1, *} \mathbb{C}$, Puneet Srivastava ${ }^{1} \mathbb{D}$ and Stephanie Shepherd ${ }^{2}$ \\ 1 Biosystems Engineering Department, Auburn University, Auburn, AL 36849, USA; \\ kzm0063@tigermail.auburn.edu (K.M.); srivapu@auburn.edu (P.S.) \\ 2 Department of Geosciences, Auburn University, Auburn, AL 36849, USA; slshepherd@auburn.edu \\ * Correspondence: js10005@auburn.edu; Tel: +1-334-844-3531
}

Received: 19 September 2018; Accepted: 29 October 2018; Published: 3 November 2018

\begin{abstract}
The elevated supply of fine-grained sediment to a river system negatively impacts the water quality and ecosystem health. Therefore, quantification of the relative contribution from different sources to in-stream sediment is of major interest to target sediment mitigation best management practices (BMPs). The objective of this study was to determine the relative contribution from different sources of suspended sediment in an urbanized watershed $\left(31 \mathrm{~km}^{2}\right)$ located in the eastern part of Alabama, USA. Estimates of relative contributions from individual source types were assessed for two different particle size fractions, 63-212 $\mu \mathrm{m}$ (fine sand) and $<63 \mu \mathrm{m}$ (silt and clay). Results of this study indicate that the construction sites were the dominant source of suspended sediment in this watershed. The average annual subwatershed-level surface runoff determined using the Soil and Water Assessment Tool (SWAT) model varied from 2.3 to $11,980 \mathrm{~mm} \mathrm{ha}^{-1}$ year $^{-1}$. Areas that generate high surface runoff have the potential to contribute disproportionately high amounts of sediment to streams and therefore should be targeted for BMPs. The results of this study show that it is important to consider spatial and temporal variability in suspended sediment sources in order to develop and target sediment control management strategies. The sources of suspended sediment and sediment deposited on the stream bed might not necessarily be the same. Therefore, sampling both suspended sediment and stream bed sediment will improve our knowledge of watershed-level sediment transport processes.
\end{abstract}

Keywords: sediment fingerprinting; suspended sediment; land use change; stream banks

\section{Introduction}

Nonpoint source (NPS) pollution has been identified as the leading cause of surface water impairment in the USA, and sediment has been considered to be the most common NPS pollutant [1,2]. Although moderate quantities of in-stream sediment are beneficial for aquatic habitats, provide nutrient enrichment to floodplain ecosystems, and ensure sediment replenishment to coastal zones $[3,4]$, elevated supplies of suspended sediment from terrestrial and aquatic sources to surface waters as a result of anthropogenic activities negatively impact aquatic ecosystems [5,6]. For example, excessive sediment delivery to surface waters can increase turbidity, deliver sediment-bound nutrients to streams and lakes, and result in sedimentation of the river bed [7]. In the state of Alabama (AL), USA, for approximately $34 \%$ of the impaired streams and rivers, sedimentation has been considered as the potential cause of impairment [8]. Thousands of miles of the rivers and streams in the southern Piedmont region of the USA are impaired because of excessive sedimentation, which can be attributed to some extent to historic disturbances during the mid-20th century $[9,10]$. With urban populations increasing at a rate of $2.1 \%$ per year, and with more than half of the world's population living in urban areas [11], the degradation of streams as a result of urbanization is significant [12]. The streams 
in urban areas are often subjected to severe impacts from human activities and land use changes, a problem recognized as 'the urban stream syndrome' [12,13]. Because of the prevalence of impervious surfaces, urban areas have the potential to generate higher volumes of overland flow, which results in increased transport of sediment to rivers and artificial drainage networks [6,14]. In urbanized watersheds, due to the connectivity between impervious surfaces and streams, even small rainfall events can result in surface runoff sufficient enough to cause disturbance to streams, thereby potentially resulting in frequent disturbance events [13].

The sediment delivered to streams via storm water runoff from construction sites has been considered the leading cause of impairment of streams and rivers in the USA and over the world [15]. Implementation of best management practices (BMPs), such as field borders, stone walls, vegetative filter strips, brush barriers, cover crops, and maintaining streamside management zones (SMZs), can help to reduce loss of sediment to streams [16-19]. However, there would be a waste of resources if control measures in a watershed were focused on reducing stream bank erosion when most of the sediment transported through a stream was contributed by surface erosion in upland areas [20]. Therefore, quantitative information on the sources of suspended sediment delivered to streams can help to target management strategies at the most important sources of suspended sediment in a watershed [21].

Sediment fingerprinting techniques have been widely used to provide information on the sources of suspended sediment in a watershed [21-24]. This technique is based on two major assumptions: first, potential sources of suspended sediment are distinguishable on the basis of selected fingerprinting properties (e.g., physical or geochemical properties), and second, the relative source contributions of different sources to suspended sediment can be determined with the comparison of fingerprinting properties in the suspended sediment and the source material samples [25]. The procedure employs statistical analysis to select a combination of fingerprinting properties that discriminate among the sources [26]. By comparing the fingerprint properties in suspended sediment and potential sources of suspended sediment using statistical testing, it is possible to obtain quantitative information on relative contributions from different sources to suspended sediment [1,27]. Different types of fingerprinting properties, such as fallout radionuclides [28,29], major and trace elemental composition [30], mineral magnetic properties [31,32], color [22,33], and stable isotopes [34,35], have been successfully used in the past to identify suspended sediment sources. However, the use of a single fingerprinting property can result in erroneous sediment source ascriptions. Therefore, multiple fingerprinting properties and multivariate statistical techniques are used to determine relative source contribution of different sources to suspended sediment. Geochemical element fingerprinting properties are the most commonly used sediment fingerprinting properties $[36,37]$ due to their ability to successfully discriminate among different sources and determine in-stream sediment sources with less uncertainty [1].

Sediment delivered to streams can originate from different sources (e.g., construction sites, cropland areas, stream banks) and contributions from different sources to suspended sediment can vary depending on the susceptibility of different soils to erosion [6]. Previous researchers have successfully used sediment fingerprinting techniques to determine relative source contributions to suspended sediment on the basis of land use types, contrasting geological zones, heterogeneous soil types, tributary sub-basins, and surficial vs. subsurface sources [24-26,38-40].

Typically, sediment fingerprinting studies have focused on the identification of suspended sediment sources in agricultural watersheds (e.g., [26,28,41,42]), and limited work has been done in urban settings (e.g., [43,44]). Although particle size exerts an important influence on relative contributions from different sources to suspended sediment [26], the effect of particle size on suspended sediment sources is rarely quantified $[27,45,46]$. Use of sediment fingerprinting in combination with watershed-level modeling can provide valuable information of watershed-level hydrological processes that affect sediment erosion and transport within a watershed. Areas generating significant amount of surface runoff have the potential to contribute disproportionately high amounts of sediment to streams $[12,13,47]$. Watershed-level modeling can help to prioritize areas based on the amount 
of surface runoff generated, and the dominant sources of suspended sediment (determined using sediment fingerprinting) in those prioritized areas can be targeted for BMPs. Several researchers have successfully used the Soil and Water Assessment Tool (SWAT) model to identify areas contributing significant amounts of surface runoff to streams [48-50], but the sediment fingerprinting technique is rarely paired with SWAT modeling to identify areas for targeting BMPs [51,52]. To our knowledge, no sediment fingerprinting study that considers the effect of particle size on sediment sources and combines SWAT modeling with sediment fingerprinting has been conducted in an urbanized watershed. Therefore, the objectives of this study were to: (a) identify sources of suspended sediment in a rapidly urbanizing watershed in southern Piedmont region of $\mathrm{AL},(\mathrm{b})$ quantify the effect of sediment particle size $(63-212 \mu \mathrm{m}$ and $<63 \mu \mathrm{m})$ on the relative contributions from different sources to suspended sediment at a subwatershed level, and (c) use the SWAT model to prioritize the subwatersheds for targeting BMPs based on the amount of surface runoff generated. The overall goal of this study was to better understand the sediment transport processes within an urbanizing watershed.

\section{Materials and Methods}

\subsection{Study Site}

Sampling was conducted in the $31 \mathrm{~km}^{2}$ watershed of the Moore's Mill Creek, located in the eastern part of AL, USA (Figure 1a). Lying within the southern Piedmont physiographic province, this watershed is a part of the lower Tallapoosa River Basin. According to the Cropland Data Layer (CDL 2017) (https://www.nass.usda.gov/Research_and_Science/Cropland/SARS1a.php), the main land uses in the study watershed are developed (66\%), forested (23\%), pasture (5\%), and shrubland (4\%). This watershed receives an average annual precipitation (1997-2017) of $1430 \mathrm{~mm}$ and experiences average annual high and low temperatures of $23^{\circ} \mathrm{C}$ and $12{ }^{\circ} \mathrm{C}$, respectively (1997-2017). Bedrock lithology ranges from schist and gneiss to saprolite and granite (https: / / datagateway.nrcs.usda.gov/). Moore's Mill Creek is listed on the Alabama Department of Environmental Management's 303(d) list of impaired water bodies because of excessive sedimentation [53]. Urbanization, historic channel modifications, reduction in riparian buffers, and agriculture have been recognized as the major contributors to this degradation [54].

a)

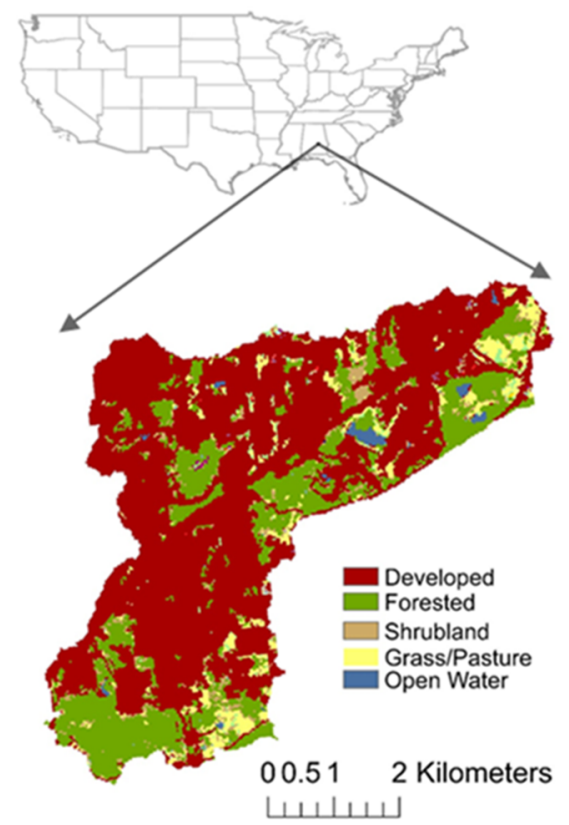

b)

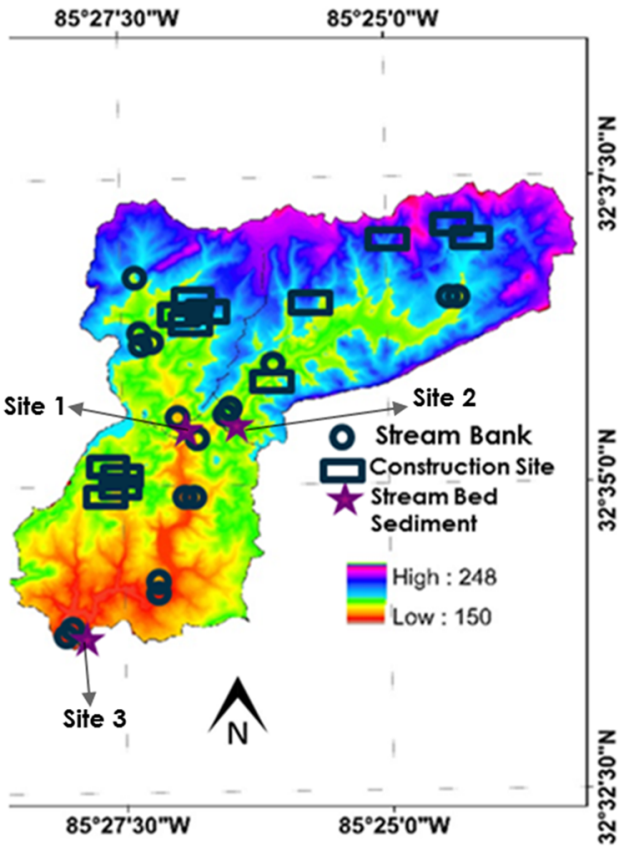

Figure 1. (a) Land use distribution in the Moore's Mill Creek watershed and (b) location of suspended sediment, stream banks, and construction sampling sites. 


\subsection{Collection of Representative Source and Suspended Sediment Samples}

The fieldwork for this study involved the collection of samples from potential sources of suspended sediment and suspended sediment sampling. The potential sources of suspended sediment considered in this study included: (1) stream banks and (2) construction sites. The source samples were collected from 30 different sites (13 samples from construction sites and 17 samples from stream banks sites) (Figure 1b).

At construction sites, 2.5-cm deep cores were collected, representing the soil susceptible to erosion. To obtain representative samples from each construction site, 10 surface soil samples were collected and composited for analysis. For stream bank sample collection, soil cores $(\sim 5 \mathrm{~cm}$ deep into the eroding face of the stream bank) within a sampling reach were collected from three different points along the eroding bank surface (top to bottom). At each site, stream bank samples were collected from five different locations and composited for analysis. This sampling protocol was followed because banks erode across the entire bank height, either by mass failure or asynchronous lower and upper bank retreat through a combination of erosion by flow scour and sub-aerial processes (including the wetting and drying of soil, which weakens the surface of stream banks) [26].

The suspended sediment samples were collected using the time-integrated suspended sediment sampler developed by Phillips et al. [55]. The time-integrated trap samplers have been successfully used in previous studies for suspended sediment sampling [33,56,57]. These samplers were installed at three sites within the watershed (Figure 1b). At each site (i.e., subwatershed or overall watershed outlet), four time-integrated trap samplers were installed to ensure that sufficient sediment mass was collected for subsequent analyses. To determine the temporal variability of suspended sediment sources, we collected suspended sediment samples from December 2016 to September 2017. The suspended sediment sample collection dates are included in Table 1.

Table 1. Suspended sediment sample collection dates throughout the sampling period.

\begin{tabular}{cc}
\hline Sites & Suspended Sediment Sample Collection Dates (Year 2017) \\
\hline 1 & 2 December, 5 February, 10 March, 14 April, 18 May, 28 June, 28 July, 22 September \\
$2 *$ & 2 December, 14 April, 18 May \\
3 & 2 December, 5 February, 10 March, 14 April, 18 May, 28 June, 28 July, 22 September \\
\hline
\end{tabular}

\subsection{Sample Preparation and Analytical Procedures}

Laboratory analysis included oven drying of both the soil and suspended sediment samples at $60{ }^{\circ} \mathrm{C}$ and disaggregation using pestle and mortar and then dry-sieving to two particle size fractions, namely $63-212 \mu \mathrm{m}$ (fine sand) and $<63 \mu \mathrm{m}$ (silt and clay). The samples were then analyzed for 59 geochemical elements, which included $\mathrm{Li}, \mathrm{Be}, \mathrm{B}, \mathrm{Mg}, \mathrm{Na}, \mathrm{Al}, \mathrm{P}, \mathrm{S}, \mathrm{K}, \mathrm{Ca}, \mathrm{Sc}, \mathrm{Ti}, \mathrm{V}, \mathrm{Cr}, \mathrm{Mn}, \mathrm{Fe}, \mathrm{Co}$, $\mathrm{Ni}, \mathrm{Cu}, \mathrm{Zn}, \mathrm{Ga}$, As, Se, Rb, Sr, Y, Zr, Nb, Rh, Pd, Ag, Mo, Cd, Sn, Sb, Cs, Ba, La, Ce, Pr, Nd, Sm, Eu, $\mathrm{Gd}, \mathrm{Dy}, \mathrm{Ho}, \mathrm{Yb}, \mathrm{Lu}, \mathrm{Hf}, \mathrm{Ta}, \mathrm{W}, \mathrm{Ir}, \mathrm{Pt}, \mathrm{Hg}, \mathrm{Tl}, \mathrm{Pb}, \mathrm{Bi}$, Th, and $\mathrm{U}$, using inductively coupled plasma mass spectrometry (ICP-MS) microwave-aided digestion (Environmental Protection Agency (EPA) Method 3052) [58] at the Wisconsin State Laboratory of Hygiene, Madison, Wisconsin, USA. Particle size analyses of suspended sediment and source samples were performed using a Malvern Mastersizer 3000 (Malvern Instruments, Worcestershire, UK) at the Geosciences Laboratory, Auburn University, Auburn, AL, USA, after a chemical dispersion with sodium hexametaphosphate $\left(50 \mathrm{~g} \mathrm{~L}^{-1}\right)$ [42]. The specific surface area of the sediment particles was determined from the particle size analysis assuming particle sphericity [41,57].

The grain size distribution of the source sediment and the suspended sediment as indicated by average D10 (diameter at which 10\% of the particle size distribution falls below), D50 (diameter at which $50 \%$ of the particle size distribution falls below), and D90 (diameter at which $90 \%$ of the particle size distribution falls below) of the sediment is included in Table 2. 
Table 2. D10, D50, and D90 * of source and suspended sediment.

\begin{tabular}{|c|c|c|c|}
\hline Sampling Location & Grain Size $(\mu \mathrm{m})$ & $63-212 \mu \mathrm{m}$ & $<63 \mu \mathrm{m}$ \\
\hline \multicolumn{4}{|c|}{ Sources } \\
\hline \multirow{3}{*}{ Construction sites } & D10 & 9.5 & 3.8 \\
\hline & D50 & 96.5 & 23.6 \\
\hline & D90 & 214.4 & 61.6 \\
\hline \multirow{3}{*}{ Stream banks } & D10 & 13.5 & 5.1 \\
\hline & D50 & 98.5 & 25.9 \\
\hline & D90 & 211.25 & 70.2 \\
\hline \multicolumn{4}{|c|}{ Suspended Sediment } \\
\hline \multirow{3}{*}{ Site 1} & D10 & 6.0 & 4.86 \\
\hline & D50 & 49.1 & 23.2 \\
\hline & D90 & 163.6 & 64.1 \\
\hline \multirow{3}{*}{ Site 2} & D10 & 6.48 & 5.08 \\
\hline & D50 & 42.2 & 22.6 \\
\hline & D90 & 150.5 & 61.9 \\
\hline \multirow{3}{*}{ Site 3} & D10 & 9.46 & 5.8 \\
\hline & D50 & 57.4 & 26.8 \\
\hline & D90 & 169.3 & 67.7 \\
\hline
\end{tabular}

* D10: Diameter at which $10 \%$ of the particle size distribution falls below, D50: Diameter at which $50 \%$ of the particle size distribution falls below, and D90: Diameter at which $90 \%$ of the particle size distribution falls below.

\subsection{Statistical Discrimination and Sediment Source Ascription}

A range test was conducted to evaluate the conservative behavior of fingerprinting properties during sediment erosion and transport processes within the watershed. This test determines whether the suspended sediment sample fingerprinting property concentrations fall within the range of source samples fingerprinting property concentrations $[39,44,59,60]$. All the non-conservative fingerprinting properties that did not satisfy this criterion were not considered for further statistical analysis. Subsequently, to select the optimum number of fingerprinting properties that discriminated between the sources successfully, a two-step statistical procedure was used [57,61,62]. In step 1, a non-parametric Mann Whitney test ( $p$-value $=0.05$ ) was used to select the fingerprinting properties that could discriminate between the source categories, namely construction sites and stream banks. The $U$ test statistic was used to test which fingerprinting properties could discriminate between sources. The properties that yielded $U$ statistic values below the critical $U$ value were considered to be successful in discriminating between source groups $[63,64]$. All the fingerprinting properties that passed the Mann Whitney test were subjected to a stepwise discriminant function analysis (DFA) to select the composite of fingerprinting properties that could provide maximum discrimination between the sources. This analysis is based on the stepwise selection algorithm of minimization of the Wilks' lambda $(\lambda)$ to select the smallest set of fingerprinting properties for discriminating between suspended sediment sources. A $\lambda$ close to 0 indicates small within-group variability as compared to variability between the source groups. The process begins with no variables (fingerprinting properties) in the model and at each step the variable that contributes most to the discriminatory power of the model, as measured by Wilk's lambda, is entered [63].

A multivariate mixing model was used to quantify the relative proportions of the source groups to suspended sediment. The mixing model involves solving a set of linear equations defined by a conservative mass balance (Equations (1)-(3)). The concentrations of fingerprinting properties within each source were multiplied by their unknown source apportionments and summed to be equal to the concentrations of the same equivalent fingerprinting properties from the suspended sediment samples [51]. The equations were solved by minimizing the sum of squares of the weighted relative errors [65]: 


$$
\sum_{j=1}^{p}\left(\frac{C_{s j}-\sum_{i=1}^{m} C_{i j} P_{i}}{C_{s j}}\right)^{2} W_{i}
$$

where $p$ is the number of fingerprinting properties in the composite fingerprint; $m$ is the number of source groups; $C_{s j}$ is the concentration of fingerprinting property $(j)$ in the suspended sediment sample; $C_{i j}$ is the mean concentration of fingerprinting property $(j)$ in the source group $i ; P_{i}$ is the relative contribution from source group (i) in the suspended sediment sample; and $W_{i}$ is the tracer discriminatory weighting factor.

Two linear boundary conditions must be satisfied by the multivariate mixing model to ensure that the relative source contributions from each source group to suspended sediment must lie between 0 and 1 and that the sum of the relative contributions from all the source groups is unity:

$$
\begin{aligned}
& \sum_{i=1}^{m} P_{i}=1 \\
& 0 \leq P_{i} \leq 1
\end{aligned}
$$

It should be noted that the relative contribution from construction sites and stream banks was determined at a subwatershed level as a function of sediment particle size. The fingerprinting property discriminatory weighting factor $\left(W_{i}\right)$ was based on the percentage of the sources classified correctly using DFA. It was used to ensure that the fingerprinting property with the greatest relative discriminatory efficiency exerted the greatest influence upon the optimized solutions [37]. The $W_{i}$ was calculated using Equation (4):

$$
W_{i}=\frac{d_{1}}{d_{2}}
$$

where $d_{1}$ is the individual property discrimination percentage and $d_{2}$ is the minimum individual property discrimination percentage of any fingerprinting property. Therefore, a $W_{i}$ value of 1.0 has the lowest influence in discriminating samples.

\subsection{Goodness-of-Fit and Uncertainty Analysis}

The goodness-of-fit of the optimized model was assessed using the relative mean error (RME) between the actual fingerprinting properties' concentrations in the suspended sediment sample and those predicted by the mixing model [44]. The RME values for each site were determined by taking the average of the relative mean error of all the fingerprinting properties concentrations within the composite signature [41]. To assess the uncertainty in the extent to which the average fingerprinting properties concentration of each source category in the mixing model reflects the true value, a Monte-Carlo simulation approach was used. This technique involved solving the mixing model by removing one sample from each source group for 1000 iterations; following this process, the mean relative source contributions were determined for each site $[59,66]$.

\subsection{SWAT Modeling}

To identify areas contributing disproportionately high amounts of surface runoff to streams, we used the Soil and Water Assessment Tool (SWAT) model. The SWAT model is a physically-based, deterministic, continuous, watershed-scale simulation model developed by the United States Department of Agriculture-Agricultural Research Service (USDA-ARS) [67,68]. In the SWAT model, a watershed is divided into subwatersheds, and each subwatershed is further divided into hydrological response units (HRUs). The HRUs are the portions of subwatersheds that possess unique land use/slope/soil attributes.

The surface runoff in each HRU was estimated using a modified Soil Conservation Service Curve Number (SCS-CN) method [68,69]. For this study, the temperature-based Hargreaves method [70] was used to estimate potential evapotranspiration (PET). A one-third arc second (10-m) resolution digital elevation model (DEM) was used to delineate the watershed and subwatershed boundaries. 
The Cropland Data Layer (CDL) for the year 2011 (USDA-CDL, 2011) developed by the National Agricultural Statistics Service was used to derive land cover parameters (https:/ / www.nass.usda.gov / Research_and_Science/Cropland/SARS1a.php). The soil data used in this study was based on the Soil Survey Geographic Database (SSURGO) developed by the USDA National Resources Conservation Service (USDA-NRCS). Weather data (daily precipitation and temperature (maximum and minimum)) was obtained from the National Oceanic and Atmospheric Administration (NOAA) weather station located near the watershed and from the Parameter-elevation Relationships on Independent Slopes Model (PRISM) climate dataset (http:/ / prism.oregonstate.edu/). The SWAT built-in weather generator was used to simulate solar radiation, wind speed, and relative humidity.

The model was calibrated separately for surface runoff and baseflow for four years (January 2011 to December 2014) and validated for three years (January 2015 to December 2017) at a monthly time-step. Using a web-based hydrograph separation program (Web-based Hydrograph Analysis Tool; WHAT), streamflow was separated into surface runoff and baseflow components [71]. The study watershed is a part of the larger Chewacla Creek watershed. The SWAT model was set up for the Chewacla Creek watershed and calibrated and validated using observed stream flow measured by the United States Geological Survey (USGS) (gage \#02418760) at the outlet of this watershed. A literature review was done to identify sensitive parameters. Curve number (CN2), available soil water capacity (Soil_AWC) (mm/mm), threshold depth of water (GWQMN) (mm), and groundwater revap coefficient (GWREVAP) parameters were used for model calibration (Table 3). Due to the unavailability of observed sediment data at the watershed outlet, the model was not calibrated and validated for sediment.

Quantitative measurements (Nash-Sutcliffe efficiency (NSE) (Equation (5)), percent bias (PBIAS) (Equation (6)) and the coefficient of determination $\left(R^{2}\right)$ (Equation (7))) along with graphical evaluations were used to assess whether the surface runoff and baseflow simulated by the SWAT model accurately represented the measured surface runoff and baseflow [72]:

$$
\begin{gathered}
N S E=1-\frac{\sum_{i=1}^{n}\left(O_{i}-P_{i}\right)^{2}}{\sum_{i=1}^{n}\left(O_{i}-O\right)^{2}} \\
P B I A S=\frac{\sum_{i=1}^{n}\left(O_{i}-P_{i}\right) * 100}{\sum_{i=1}^{n} O_{i}} \\
R^{2}=\frac{\sum_{i=1}^{n}\left(O_{i}-O\right)\left(P_{i}-P\right)}{\sqrt{\sum_{i=1}^{n}\left(O_{i}-O\right)^{2}} \sqrt{\sum_{i=1}^{n}\left(P_{i}-P\right)^{2}}}
\end{gathered}
$$

where $O_{i}$ is the $i$ th observation for the constituent being evaluated; $P_{i}$ is the $i$ th simulated value for the constituent being evaluated; $O$ is the mean of observed data for the constituent being evaluated; $P$ is the mean of simulated data for the constituent being evaluated; and $n$ is the total number of observations.

Table 3. Parameters used for SWAT model calibration.

\begin{tabular}{ccc}
\hline SWAT Calibration Parameter & Default Value & Final Calibrated Value \\
\hline Soil_AWC $(\mathrm{mm} / \mathrm{mm})$ & Varies & $15 \%$ increase \\
GWREVAP (dimensionless) & 0.02 & 0.2 \\
CN2 (dimensionless) & Varies & $10 \%$ decrease \\
GWQMN $(\mathrm{mm})$ & 1000 & 3907 \\
\hline
\end{tabular}

\subsection{Land Use Change Scenario}

To better understand the effect of the increase in urbanization within the watershed on surface runoff, a land use scenario was performed. This land use change scenario involved change of forested areas to urban areas, which is a widespread trend in the Moore's Mill Creek watershed. This is evident from the increase of urbanized area from $44 \%$ to $65 \%$ and decrease of forested area from $41 \%$ to 
23\% from 2008 to 2017 (CDL, 2008-2017). The influence of the land use change was quantified by comparing the SWAT outputs of surface runoff before and after the land use change scenario at the subwatershed level.

\section{Results}

\subsection{Optimum Fingerprinting Properties}

The fingerprinting properties that passed the range test and Mann Whitney test ( $p$-value $=0.05$ ) for both the particle sizes, namely $63-212 \mu \mathrm{m}$ and $<63 \mu \mathrm{m}$, at each site are included in Tables 4 and 5, respectively. Out of 59 fingerprinting properties, the majority passed the range test, indicating that those fingerprinting properties possessed conservative behavior. Based on the results of the Mann Whitney test, the number of fingerprinting properties that successfully discriminated between the construction sites and stream banks at all sites for the two particle sizes ranged from 9 to 21 (Tables 4 and 5).

The results of the stepwise DFA on the fingerprinting properties that passed the Mann Whitney test for 63-212 $\mu \mathrm{m}$ and $<63 \mu \mathrm{m}$ particle size fractions at each site are shown in Tables 6 and 7, respectively. The optimum number of fingerprinting properties that provided the greatest discrimination between construction sites and stream banks for the two particle sizes ranged from 3 to 6 among all sites and classified $>90 \%$ of the sources correctly at each site. The cumulative percentage of source samples classified correctly varied from $96.7 \%$ to $100 \%$ for $63-212 \mu \mathrm{m}$ particle size fractions, whereas for $<63 \mu \mathrm{m}$ particle size fractions, optimum number of fingerprinting properties classified $100 \%$ of the source samples correctly at each site. For all the monitoring sites, good source discrimination was achieved based on the values of Wilks' lambda, which ranged from 0.022 to 0.153 and 0.025 to 0.107 for 63-212 $\mu \mathrm{m}$ and $<63 \mu \mathrm{m}$ particle size fractions, respectively.

The concentrations of geochemical elements in soils depend on parent material, climate, hydrology, amount and types of vegetation, weathering processes, and anthropogenic activities [7,73]. Out of all the fingerprinting properties selected as a part of the composite fingerprint for all sites, the fingerprinting properties that had association with anthropogenic sources (e.g., $\mathrm{Ni}, \mathrm{V}$, and $\mathrm{Pb}$ ) were found to have greater concentrations in soils collected from construction sites compared to concentrations in samples collected from stream banks. Heavy metals have been observed to be less concentrated in sub-soils than surface soils [73]. The higher concentration of Ni (considered a heavy metal of environmental concern in urban areas) in soil collected from construction sites reflected the effect of anthropogenic activities on deposition of $\mathrm{Ni}$ in the surface soils [74,75]. Metal Vanadium has been extensively used for making steel alloys for tools and construction purposes [76]. Metal Lead, another toxic heavy metal, is widely used in building construction and is known to be anthropogenic source of soil contaminant [77]. Therefore, the concentrations of $\mathrm{V}$ and $\mathrm{Pb}$ were higher in soils collected from construction sites. Concentrations of rare earth elements (e.g., $\mathrm{Pr}, \mathrm{Eu}$ ) were greater in stream banks compared to construction sites. Generally, concentrations of rare earth elements are higher in sub-soils and parent material as compared to surface soils [78]. Because stream banks are composed of less weathered sub-surface material, concentrations of rare earth elements were greater in stream banks than construction sites $[26,57]$. 
Table 4. Fingerprinting properties that satisfied the mass-conservative and the Mann Whitney test $(p$-value $=0.05)$ criteria at each site for particle sizes $63-212 \mu \mathrm{m}$.

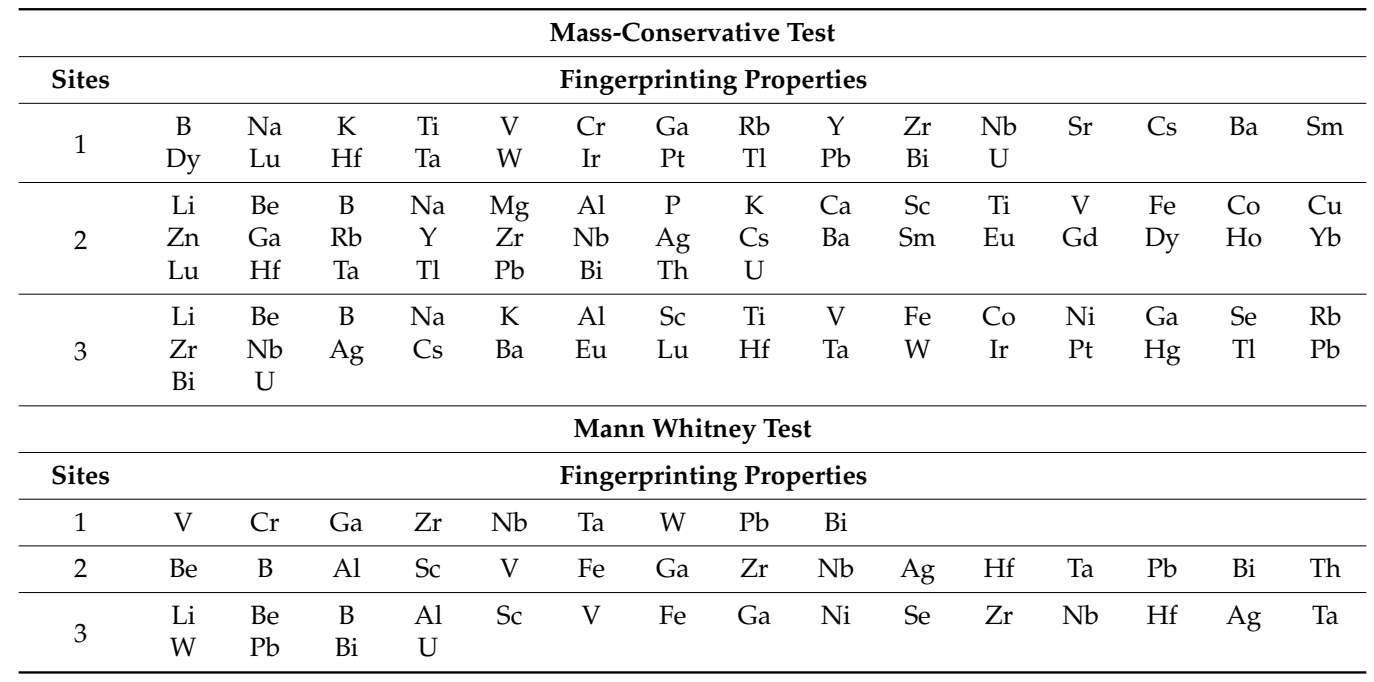

Table 5. Fingerprinting properties that satisfied the mass-conservative and the Mann Whitney test $(p$-value $=0.05)$ criteria at each site for particle sizes $<63 \mu \mathrm{m}$.

\begin{tabular}{|c|c|c|c|c|c|c|c|c|c|c|c|c|c|c|c|}
\hline \multicolumn{16}{|c|}{ Mass-Conservation Test } \\
\hline Sites & \multicolumn{15}{|c|}{ Fingerprinting Properties } \\
\hline \multirow{3}{*}{1} & $\mathrm{Li}$ & $\mathrm{Be}$ & B & $\mathrm{Na}$ & $\mathrm{P}$ & $\mathrm{K}$ & Sc & $\mathrm{Ti}$ & $\mathrm{V}$ & $\mathrm{Cr}$ & $\mathrm{Fe}$ & Co & $\mathrm{Ni}$ & $\mathrm{Ga}$ & As \\
\hline & $\mathrm{Rb}$ & $\mathrm{Zr}$ & $\mathrm{Nb}$ & Mo & $\mathrm{Cd}$ & Cs & $\mathrm{Ba}$ & $\operatorname{Pr}$ & $\mathrm{Eu}$ & $\mathrm{Gd}$ & Та & W & $\mathrm{Ir}$ & $\mathrm{Pt}$ & $\mathrm{Hg}$ \\
\hline & $\mathrm{Tl}$ & $\mathrm{Pb}$ & $\mathrm{Bi}$ & $\mathrm{U}$ & & & & & & & & & & & \\
\hline \multirow{2}{*}{2} & $\mathrm{Li}$ & $\mathrm{Be}$ & $\mathrm{Mg}$ & $\mathrm{Al}$ & $\mathrm{K}$ & Sc & V & $\mathrm{Cr}$ & $\mathrm{Fe}$ & Co & $\mathrm{Ni}$ & $\mathrm{Zn}$ & $\mathrm{Ga}$ & As & $\mathrm{Zr}$ \\
\hline & $\mathrm{Nb}$ & $\mathrm{Cd}$ & $\mathrm{Cs}$ & $\mathrm{Ba}$ & $\mathrm{Nd}$ & $\mathrm{Lu}$ & Hf & $\mathrm{Ta}$ & W & Ir & $\mathrm{Pt}$ & $\mathrm{Tl}$ & $\mathrm{Pb}$ & $\mathrm{Bi}$ & $\mathrm{U}$ \\
\hline \multirow{3}{*}{3} & $\mathrm{Li}$ & $\mathrm{Be}$ & B & $\mathrm{Na}$ & $\mathrm{Al}$ & K & $\mathrm{Sc}$ & $\mathrm{V}$ & $\mathrm{Cr}$ & $\mathrm{Fe}$ & Co & $\mathrm{Ni}$ & Ga & As & $\mathrm{Rb}$ \\
\hline & $\mathrm{Zr}$ & $\mathrm{Nb}$ & $\mathrm{Cd}$ & $\mathrm{Sb}$ & Cs & $\mathrm{Ba}$ & $\operatorname{Pr}$ & $\mathrm{Eu}$ & $\mathrm{Hf}$ & Ta & $\mathrm{W}$ & $\mathrm{Ir}$ & $\mathrm{Pt}$ & $\mathrm{Hg}$ & $\mathrm{Tl}$ \\
\hline & $\mathrm{Pb}$ & $\mathrm{Bi}$ & $\mathrm{U}$ & & & & & & & & & & & & \\
\hline \multicolumn{16}{|c|}{ Mann Whitney Test } \\
\hline Sites & \multicolumn{15}{|c|}{ Fingerprinting Properties } \\
\hline & $\mathrm{Be}$ & $\mathrm{Sc}$ & $\mathrm{V}$ & Co & $\mathrm{Ga}$ & As & $\mathrm{Rb}$ & $\mathrm{Nb}$ & $\mathrm{Cd}$ & $\mathrm{Ba}$ & $\mathrm{Pr}$ & $\mathrm{Eu}$ & $\mathrm{Gd}$ & $\mathrm{Ta}$ & Ir \\
\hline 1 & $\mathrm{Pt}$ & $\mathrm{Pb}$ & $\mathrm{Bi}$ & & & & & & & & & & & & \\
\hline 2 & Be & $\mathrm{V}$ & $\mathrm{Cr}$ & $\mathrm{Fe}$ & $\mathrm{Ni}$ & Ga & $\mathrm{Zr}$ & $\mathrm{Cd}$ & $\mathrm{Hf}$ & $\mathrm{Ir}$ & $\mathrm{Pt}$ & $\mathrm{Bi}$ & $\mathrm{U}$ & & \\
\hline \multirow{2}{*}{3} & $\mathrm{Be}$ & B & V & $\mathrm{Cr}$ & $\mathrm{Fe}$ & Co & $\mathrm{Ni}$ & $\mathrm{Ga}$ & $\mathrm{Rb}$ & $\mathrm{Zr}$ & $\mathrm{Cd}$ & Ва & $\operatorname{Pr}$ & $\mathrm{Eu}$ & $\mathrm{Hf}$ \\
\hline & $\mathrm{Ta}$ & $\mathrm{Ir}$ & $\mathrm{Pt}$ & $\mathrm{Pb}$ & $\mathrm{Bi}$ & $\mathrm{U}$ & & & & & & & & & \\
\hline
\end{tabular}

Table 6. Results of stepwise discriminant function analysis (DFA) at each site for particle sizes 63-212 $\mu \mathrm{m}$.

\begin{tabular}{cccccc}
\hline Site & $\begin{array}{c}\text { Fingerprinting } \\
\text { Property }\end{array}$ & $\begin{array}{c}\text { Wilks' } \\
\text { Lambda }\end{array}$ & $\begin{array}{c}\text { Percentage of } \\
\text { Source Samples } \\
\text { Classified } \\
\text { Correctly }\end{array}$ & $\begin{array}{c}\text { Cumulative Percentage } \\
\text { of Source Samples } \\
\text { Classified Correctly }\end{array}$ & $\begin{array}{c}\text { Tracer } \\
\text { Discriminatory } \\
\text { Weighting }\end{array}$ \\
\hline \multirow{2}{*}{1} & $\mathrm{Bi}$ & 0.151 & 100 & 100 & 1.18 \\
& $\mathrm{Ga}$ & 0.101 & 84.6 & 100 & 1.00 \\
& $\mathrm{~Pb}$ & 0.074 & 84.6 & 100 & 1.00 \\
$\mathrm{Ta}$ & 0.040 & 84.6 & 100 & 1.00 \\
\hline & $\mathrm{V}$ & 0.055 & 100 & 100 & 1.10 \\
& $\mathrm{~Pb}$ & 0.037 & 100 & 100 & 1.10 \\
& $\mathrm{Bi}$ & 0.022 & 90 & 96.7 & 1.00 \\
& $\mathrm{~V}$ & 0.286 & 96.7 & 93.3 & 1.24 \\
& $\mathrm{Ag}$ & 0.259 & 86.67 & 93.3 & 1.14 \\
$\mathrm{~Pb}$ & 0.229 & 80.00 & 96.7 & 1.00 \\
& $\mathrm{Se}$ & 0.181 & 80.00 & 96.7 & 1.14 \\
\hline
\end{tabular}


Table 7. Results of stepwise DFA at each site for particle sizes 63-212 $\mu \mathrm{m}$.

\begin{tabular}{|c|c|c|c|c|c|}
\hline Site & $\begin{array}{c}\text { Fingerprinting } \\
\text { Property }\end{array}$ & $\begin{array}{c}\text { Wilks' } \\
\text { Lambda }\end{array}$ & $\begin{array}{l}\text { Percentage of Source } \\
\text { Samples Classified } \\
\text { Correctly }\end{array}$ & $\begin{array}{c}\text { Cumulative Percentage } \\
\text { of Source Samples } \\
\text { Classified Correctly }\end{array}$ & $\begin{array}{c}\text { Tracer } \\
\text { Discriminatory } \\
\text { Weighting }\end{array}$ \\
\hline \multirow{3}{*}{1} & $\mathrm{Bi}$ & 0.049 & 100 & 100 & 1.3 \\
\hline & $\mathrm{Ir}$ & 0.032 & 84.6 & 100 & 1.1 \\
\hline & $\mathrm{Ba}$ & 0.025 & 76.9 & 100 & 1.0 \\
\hline \multirow{3}{*}{2} & $\mathrm{Ga}$ & 0.198 & 100 & 100 & 1.25 \\
\hline & $\mathrm{Ni}$ & 0.152 & 80 & 100 & 1 \\
\hline & $\mathrm{Bi}$ & 0.107 & 80 & 100 & 1 \\
\hline \multirow{6}{*}{3} & $\mathrm{Rb}$ & 0.152 & 76.67 & 76.67 & 1.04 \\
\hline & $\mathrm{U}$ & 0.122 & 73.33 & 86.7 & 1.00 \\
\hline & $\mathrm{Zr}$ & 0.091 & 86.67 & 100 & 1.18 \\
\hline & $\operatorname{Pr}$ & 0.070 & 80 & 100 & 1.09 \\
\hline & $\mathrm{Eu}$ & 0.064 & 76.67 & 100 & 1.04 \\
\hline & $\mathrm{Ni}$ & 0.038 & 80 & 100 & 1.09 \\
\hline
\end{tabular}

\subsection{Sediment Source Ascription}

The relative source contributions of stream banks and construction sites to suspended sediment (for both particle size fractions) at each site are shown in Figures $2 a-c$ and $3 a-c$. At site 1, construction sites were the dominant contributors to suspended sediment, with the relative source contributions ranging from $51 \%$ to $71 \%$ for particle sizes $63-212 \mu \mathrm{m}$ (Figure 2a). For $<63 \mu \mathrm{m}$ particle sizes, the relative source contributions from construction sites ranged from $28 \%$ to $100 \%$, (Figure 3a). This subwatershed has experienced an increase in urban land cover from $63 \%$ to $81 \%$ and a decrease in forested land cover from 29\% to 15\% from 2008 to 2017 based on Cropland Data Layer (CDL 2008 and 2017) (https://www.nass.usda.gov/Research_and_Science/Cropland/SARS1a.php). Urbanization of a watershed typically results in increase in storm water runoff; as such, the increased urbanization in the area surrounding our study site likely increased erosion from the construction sites in this subwatershed. Additionally, increased urbanization is accompanied by increased discharge and stream power, resulting in destabilization of nearby streams [79], which could have induced stream bank erosion in this subwatershed. Different mechanisms leading to stream bank failures include flow-induced erosion of bank material and the geotechnical instability phenomenon. In the former, the hydraulic flow erodes the sediment and the failed material releases to the toe of the bank and, due to cohesive nature of the bank, the failed material remains at the bank toe. However, the latter results from the bank moisture problems, which leads to geotechnical instability, due to submergence $[80,81]$.

At site 2, both stream banks and construction sites were the dominant sources of suspended sediment for both the particle size fractions. For 63-212 $\mu \mathrm{m}$ particles, the contribution from stream banks and construction sites ranged from $29 \%$ to $85 \%$ and from $15 \%$ to $71 \%$, respectively (Figure $2 b$ ). The relative contributions from stream banks and construction sites ranged from $45 \%$ to $100 \%$ and from $0 \%$ to $55 \%$, respectively for $<63 \mu \mathrm{m}$ particles (Figure $3 \mathrm{~b}$ ). The land use categorized as developed in this subwatershed increased from $42 \%$ to $61 \%$ with an accompanying decrease of forested cover from $42 \%$ to $24 \%$ from 2008 to 2017 based on the Cropland Data Layer (CDL 2008 and 2017) (https: / / www. nass.usda.gov/Research_and_Science/Cropland/SARS1a.php). It has been found that an increase in imperviousness leads to increases in specific stream power and hence the risk of stream instability [79], which could have led to increased contribution from the stream banks to suspended sediment in our study area. Furthermore, storm water runoff generated in this subwatershed (developed land use- $61 \%$ ) likely caused erosion from construction sites. The dataset at this site was limited compared to other sites because time-integrated suspended sediment samplers were lost for most of the sampling period at this site.

Compared to site 1 and site 2, contributions from construction sites to suspended sediment at site 3 were greater. The contributions from stream banks and construction sites ranged from $0 \%$ to $34 \%$ and from $66 \%$ to $100 \%$, respectively for $63-212 \mu \mathrm{m}$ particles (Figure 2c). For $<63 \mu \mathrm{m}$ particles, the relative contribution to suspended sediment from stream banks and constructions sites ranged from $0 \%$ to 
$46 \%$ and 54 to $100 \%$, respectively (Figure 3c). Land disturbance as a result of construction activities exposes large areas of bare soil to erosion by water, increasing soil erosion rates to 2-40,000 times preconstruction and agricultural rates [2]. A small portion (3\%) of the watershed (Figure 4) was occupied by active construction sites in 2017. However, soil erosion rates from construction sites (which can approach up to $500 \mathrm{~T} \mathrm{ha}^{-1}$ year $^{-1}$ ) are considerably higher than those from areas occupied by undisturbed vegetation $\left(<1 \mathrm{~T} \mathrm{ha}^{-1}\right.$ year $\left.^{-1}\right)$ [10], which likely resulted in greater contribution from construction sites to suspended sediment. Moreover, greater relative contribution from construction sites to suspended sediment at site 3 could be attributed to the existence of construction sites in the subwatershed without enough riparian buffer. Riparian buffers have been known to effectively intercept sediment from the surface runoff [82]. However, on analyzing a 9 meter buffer on each side of the stream at all sites, it was observed that the reach at site 3 had more developed areas ( $30 \%$ forested areas within the buffer) adjacent to the stream as compared to other sites ( $40 \%$ and $55 \%$ forested areas within the buffer at site 1 and 2, respectively). Since the reach at site 3 had less percentage of riparian area under forested land use, it likely increased the delivery of sediment from construction sites to streams. Therefore, as mentioned earlier in the manuscript, an increase in urbanization increases the surface runoff, which leads to entrainment of sediment from construction sites (for which the erosion rates are very high) in the storm water runoff and results in increased delivery of sediment into the surface water bodies. However, it should be noted that after the construction ends, the developed areas would continue to yield water to streams, but likely with lesser amounts of sediment load. Higher amounts of surface runoff generated from the developed area could increase the stream power, which could increase bank erosion in the downstream channels.

The decrease in the contribution of stream banks downstream could be attributed to the decrease in the channel slope and shear stress downstream. The upstream reaches had more gradient as compared to the reach downstream, which could result in the reduction of shear velocity downstream. The average shear stress exerted on the reach at site 1 and 2 was 4.73 and $4.97 \mathrm{~kg} \mathrm{~m}^{-2}$, respectively, whereas on the reach at site 3 it was $1.80 \mathrm{~kg} \mathrm{~m}^{-2}$. The shear stress values were calculated using equation $\tau=\gamma \operatorname{Rs}\left(\mathrm{kg} \mathrm{m}^{-2}\right)$, where $\tau$ is the fluid shear stress, $\gamma$ is the specific weight of water, $R$ is the hydraulic radius, and $s$ is the slope of the channel [83]. Therefore, the shear stress on the channel banks likely resulted in reduced relative contribution from stream banks to suspended sediment in the site 3 watershed.

The temporal variability in the suspended sediment sources during the sampling period was likely affected by the phase of construction activity (from the commencement to completion of construction sites) located within this watershed. A construction project begins with site work, which involves land clearance and the excavation of soils, and ends with grading and landscaping [2]. Construction practices that have been identified as contributing to high sediment yields include land clearance exposing the bare soil, stripping topsoil, piling the excavated soil near or on the streets, and the tracking of mud in the streets by construction vehicles [84]. Additionally, the temporal variability in suspended sediment sources depends upon the 'lag time' between the erosion of sediment from the construction site and the consequent delivery of sediment to the creek, which depends upon the phase of the construction activity and the temporary retention or storage of sediment within the watershed. 

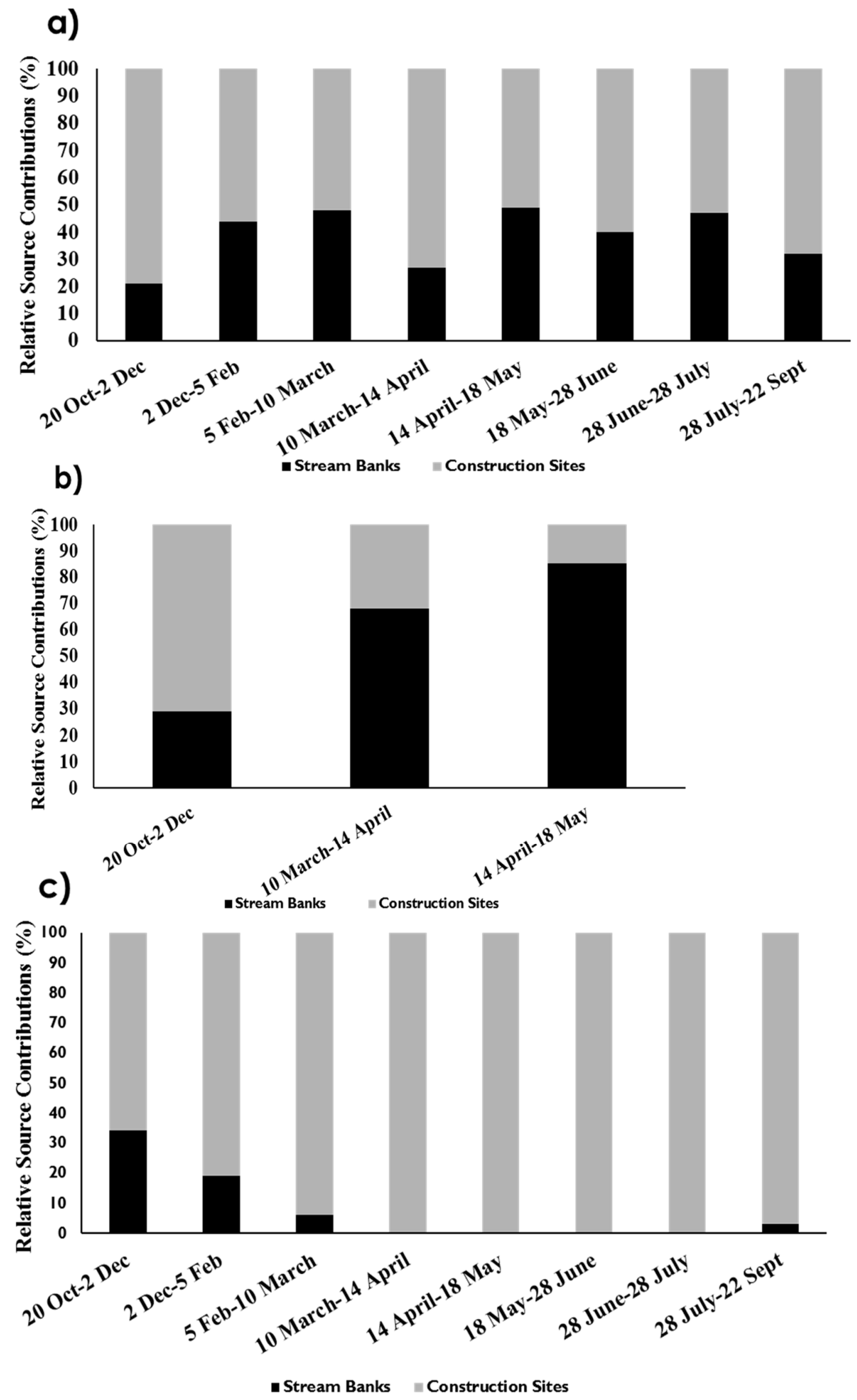

Figure 2. Relative source contribution (\%) to suspended sediment (for particle sizes 63-212 $\mu \mathrm{m}$ ) from stream banks and construction sites at: (a) site 1, (b) site 2, and (c) site 3. 


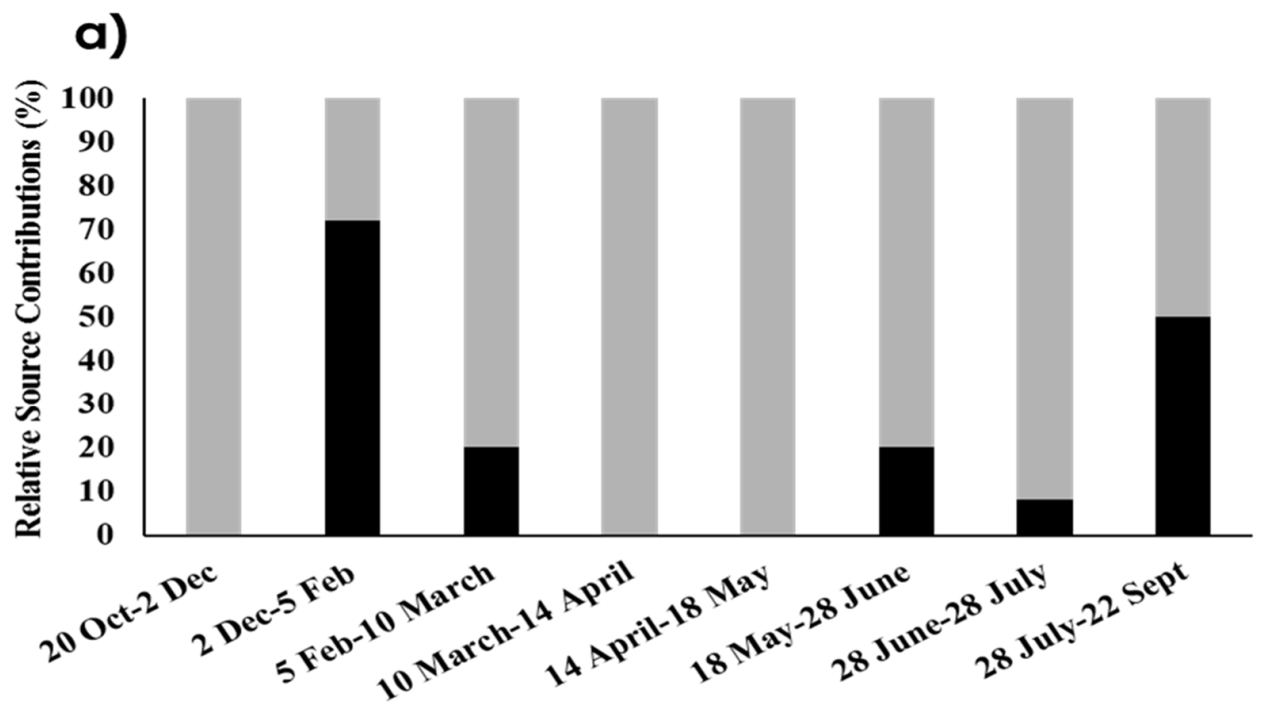

b)

- Stream Banks $\quad$ Construction Sites

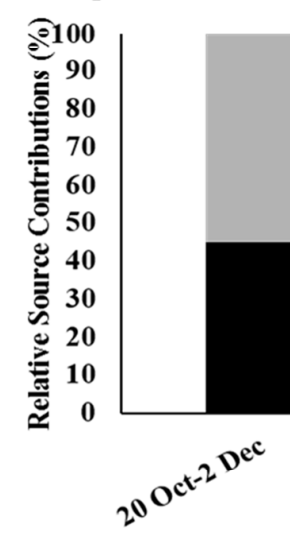

c)
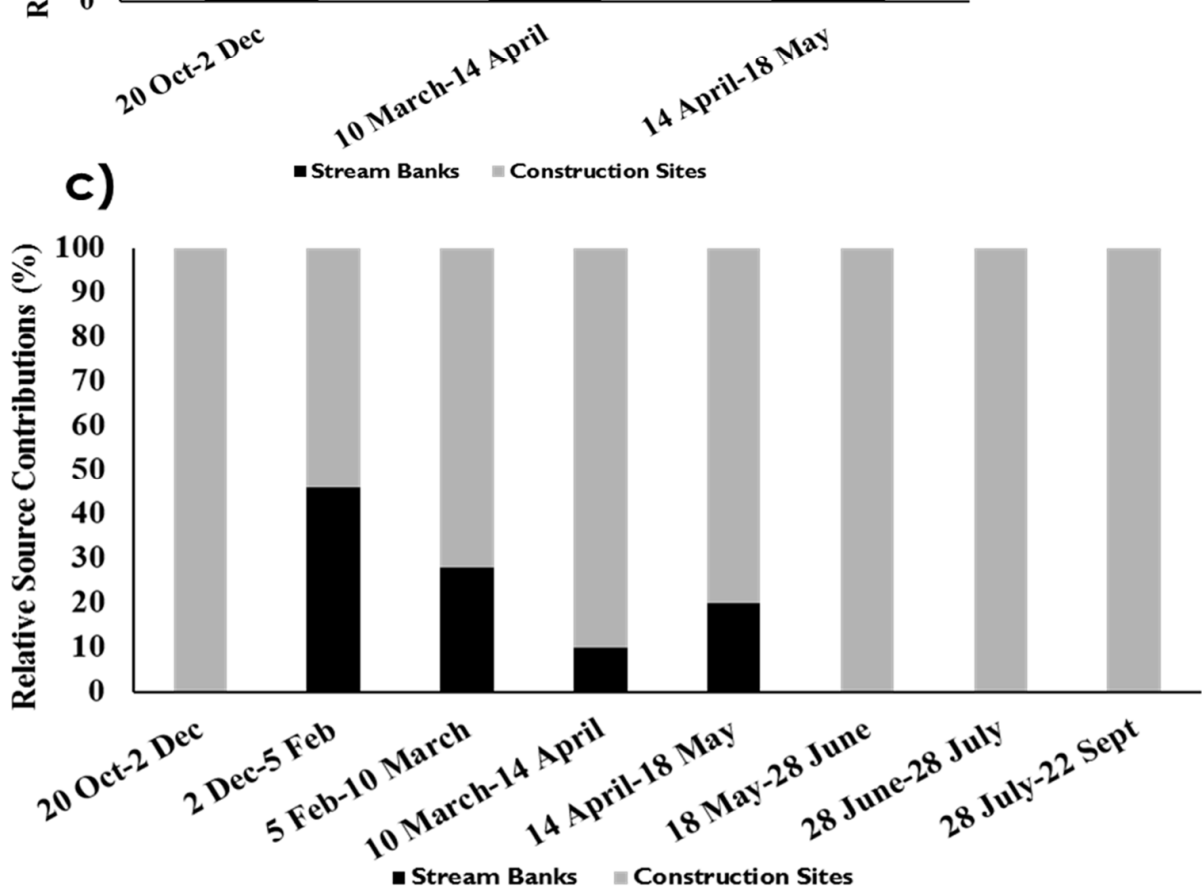

Figure 3. Relative source contributions (\%) to suspended sediment (for particle sizes $<63 \mu \mathrm{m}$ ) from stream banks and construction sites at: (a) site 1, (b) site 2, and (c) site 3. 


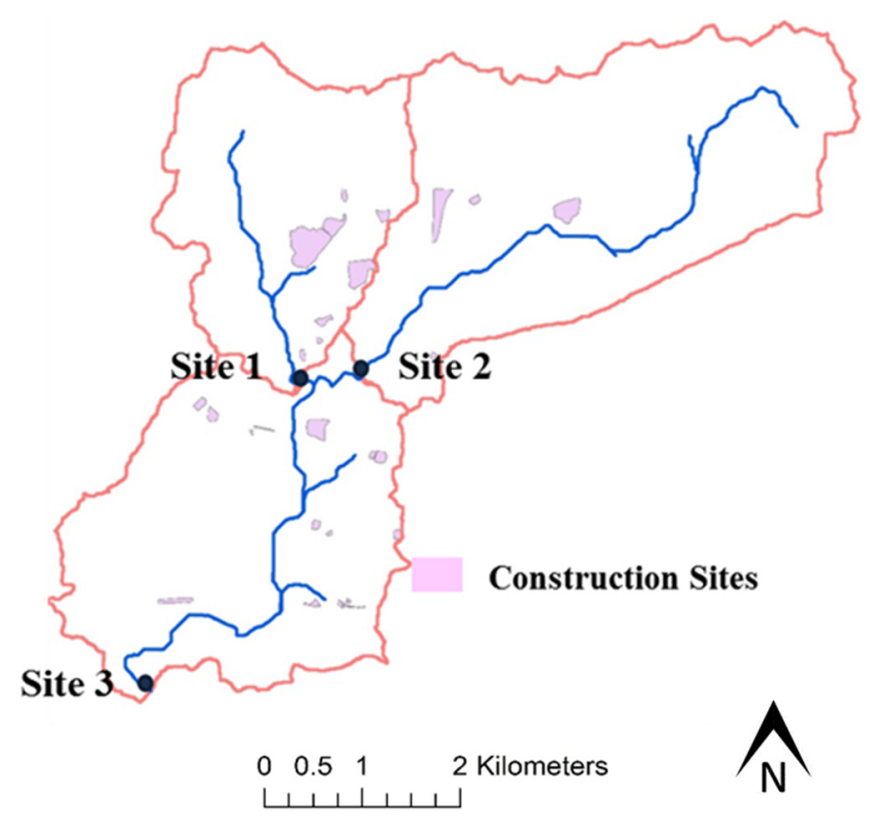

Figure 4. Active construction sites in the watershed in the year 2017.

\subsection{Comparison between Suspended and Stream Bed Sediment Sources}

The results of this study show that the relative source contributions from different sources to suspended sediment and stream bed sediment might not be always similar. For example, a previous study conducted by the authors in this watershed [85] showed that the dominant sources of bed sediment (for both the particle sizes, 63-212 $\mu \mathrm{m}$ and $<63 \mu \mathrm{m}$ ) at site 1 and 2 were stream banks. However, for suspended sediment, construction sites were the dominant sources of suspended sediment at site 1 , whereas both stream banks and construction sites were the important sources of suspended sediment at site 2 .

Suspended sediment had greater specific surface area or was finer in size (average specific surface area was $132.3 \pm 8.7 \mathrm{~m}^{2} \mathrm{~kg}^{-1}$ and $170.6 \pm 9.1 \mathrm{~m}^{2} \mathrm{~kg}^{-1}$ for particle sizes $63-212 \mu \mathrm{m}$ and $<63 \mu \mathrm{m}$, respectively) compared to stream bed sediment (average specific surface area was $60 \pm 4.2 \mathrm{~m}^{2} \mathrm{~kg}^{-1}$ and $120.6 \pm 5.9 \mathrm{~m}^{2} \mathrm{~kg}^{-1}$ for particle sizes $63-212 \mu \mathrm{m}$ and $<63 \mu \mathrm{m}$, respectively). The sediment from construction sites were finer (average specific surface area was $129.91 \pm 9.6 \mathrm{~m}^{2} \mathrm{~kg}^{-1}$ and $291.26 \pm 24.5 \mathrm{~m}^{2} \mathrm{~kg}^{-1}$ for the particle sizes $63-212 \mu \mathrm{m}$ and $<63 \mu \mathrm{m}$, respectively) compared to sediment from stream banks (average specific surface area was $114.35 \pm 6.4 \mathrm{~m}^{2} \mathrm{~kg}^{-1}$ and $212.7 \pm 9.5 \mathrm{~m}^{2} \mathrm{~kg}^{-1}$ for the particle sizes $63-212 \mu \mathrm{m}$ and $<63 \mu \mathrm{m}$, respectively). Finer particles (eroded from construction sites) will remain suspended in streams, compared to coarse particles, which will settle at a faster rate on the stream bed. Therefore, constructions sites were the dominant sources of suspended sediment. Depending upon the hydraulic forces exerted during flow events, sediment eroded from stream banks can be present in the stream as individual particles or aggregates (e.g., due to stream bank mass failure) [57]. The aggregates will deposit on the stream, therefore stream banks were the dominant sources of sediment deposited on the stream bed.

To identify the dominant sources of sediment in a watershed, stream bed sediment sampling has been used as an alternative to sampling suspended sediment [57]. However, as indicated by the results of this study, it is important to recognize that the dominant sources of stream bed sediment and suspended sediment in a watershed might not necessarily be similar. For example, in a study [57] conducted in an agricultural watershed located in Wisconsin, USA, it was reported that the dominant sources of suspended sediment and stream bed sediment were not the same. Therefore, the identification of sources of both the suspended and stream bed sediment is needed in order to target management practices effectively and efficiently. The results of this study have important implications for the design of effective sediment control strategies. For example, reducing stream bank erosion 
is unlikely to prove an effective means of significantly reducing suspended sediment loads in the site 1 subwatershed, since construction sites were the dominant sources of suspended sediment in this subwatershed.

\subsection{Goodness-of-Fit and Uncertainty Analysis}

The RME values calculated to assess the goodness-of-fit of the mixing model indicated that the mixing model provided satisfactory agreement between predicted and actual suspended sediment fingerprinting properties concentration. The RME values ranged from $4 \%$ to $29 \%, 8 \%$ to $21 \%$, and $8 \%$ to $31 \%$ at site 1,2 , and 3, respectively, for both particle size fractions (Table 8 ). The majority of RME values were less than $25 \%$, indicating that the mixing model satisfactorily predicted the concentrations of fingerprinting properties in suspended sediment [57]. The relative source contribution differences obtained from the average of the Monte Carlo results and the corresponding values obtained from the mixing model using the mean source fingerprinting property concentrations ranged from $0 \%$ to $3 \%$, $0 \%$ to $7 \%$, and $0 \%$ to $11 \%$ at site 1,2 , and 3, respectively, for both particle size fractions. The Monte Carlo results show that the use of mean fingerprinting property concentrations of the source samples in the mixing model was not a significant source of uncertainty. 
Table 8. Relative mean error (\%) between actual and optimized mixing model predicted suspended sediment fingerprinting property concentrations.

\begin{tabular}{|c|c|c|c|c|c|c|c|c|}
\hline & \multicolumn{2}{|c|}{ Relative Mean Error (\%) } & \multicolumn{4}{|c|}{ Relative Mean Error (\%) } & \multicolumn{2}{|c|}{ Relative Mean Error (\%) } \\
\hline & Site 1 & & & Site 2 & & & Site 3 & \\
\hline Month & $63-212 \mu \mathrm{m}$ & $<63 \mu \mathrm{m}$ & Month & $63-212 \mu \mathrm{m}$ & $<63 \mu \mathrm{m}$ & Month & $63-212 \mu \mathrm{m}$ & $<63 \mu \mathrm{m}$ \\
\hline 20 October-2 December & 20 & 6 & 20 October-2 December & 21 & 17 & 20 October-2 December & 24 & 25 \\
\hline 2 December-5 February & 9 & 10 & 2 December-February & $-*$ & $-*$ & 2 December-February & 22 & 29 \\
\hline 5 February-10 March & 4 & 14 & 5 February-10 March & $-*$ & $-*$ & 5 February-10 March & 25 & 25 \\
\hline 10 March-14 April & 22 & 12 & 10 March-14 April & 11 & 14 & 10 March-14 April & 31 & 15 \\
\hline 14 April-18 May & 18 & 11 & 14 April-18 May & 15 & 8 & 14 April-18 May & 30 & 14 \\
\hline 18 May-28 June & 17 & 9 & 18 May-28 June & $-*$ & $-*$ & 18 May-28 June & 10 & 8 \\
\hline 28 June-28 July & 10 & 29 & 28 June-28 July & $-*$ & $-*$ & 28 June-28 July & 27 & 13 \\
\hline 28 July-22 September & 12 & 22 & 28 July-22 September & $-*$ & $-*$ & 28 July-22 September & 18 & 25 \\
\hline
\end{tabular}

${ }^{*}$ Data not available because suspended sediment samplers were lost. 


\subsection{SWAT Model Calibration and Validation}

The time series of observed vs. simulated surface runoff, baseflow, and total stream flow show that the SWAT model successfully captured changes in surface runoff, baseflow, and stream flow on a monthly time-step (Figure $5 \mathrm{a}-\mathrm{c}$ ). The statistical values calculated for calibration and validation time periods for surface runoff, baseflow, and total stream flow are presented in Table 9.

Very good model calibration and validation results were obtained, as indicated by the NSE and $R^{2}$ values for surface runoff, baseflow, and stream flow. Based on the values of PBIAS for surface runoff, baseflow, and stream flow, model performance rating was "satisfactory" for the calibration time period and "very good" for the validation time period [72]. Overall, the SWAT model satisfactorily simulated changes in monthly surface runoff, baseflow, and total stream flow.

Table 9. Calibration and validation metrics for monthly surface runoff $\left(\mathrm{m}^{3} / \mathrm{s}\right)$, base flow $\left(\mathrm{m}^{3} / \mathrm{s}\right)$, and total flow $\left(\mathrm{m}^{3} / \mathrm{s}\right)$.

\begin{tabular}{ccccccc}
\hline & \multicolumn{2}{c}{ Calibration (January 2011-December 2014) } & \multicolumn{2}{c}{ Validation (January 2015-December 2017) } \\
\hline Variable & $\boldsymbol{R}^{2 * *}$ & NSE & PBIAS ** & $\boldsymbol{R}^{\mathbf{2}}$ & NSE & PBIAS \\
\hline Surface Runoff $\left(\mathrm{m}^{3} / \mathrm{s}\right)$ & 0.84 & 0.77 & 18.5 & 0.83 & 0.82 & -6.5 \\
Baseflow $\left(\mathrm{m}^{3} / \mathrm{s}\right)$ & 0.85 & 0.75 & 18.8 & 0.90 & 0.88 & -9.3 \\
Total Stream Flow $\left(\mathrm{m}^{3} / \mathrm{s}\right)$ & 0.86 & 0.77 & 18.6 & 0.84 & 0.83 & -7.5 \\
\hline
\end{tabular}

${ }^{*}$ Nash-Sutcliffe Efficiency, ${ }^{* *}$ Percent Bias (PBIAS), ${ }^{* * *}$ Coefficient of Determination $\left(R^{2}\right)$.

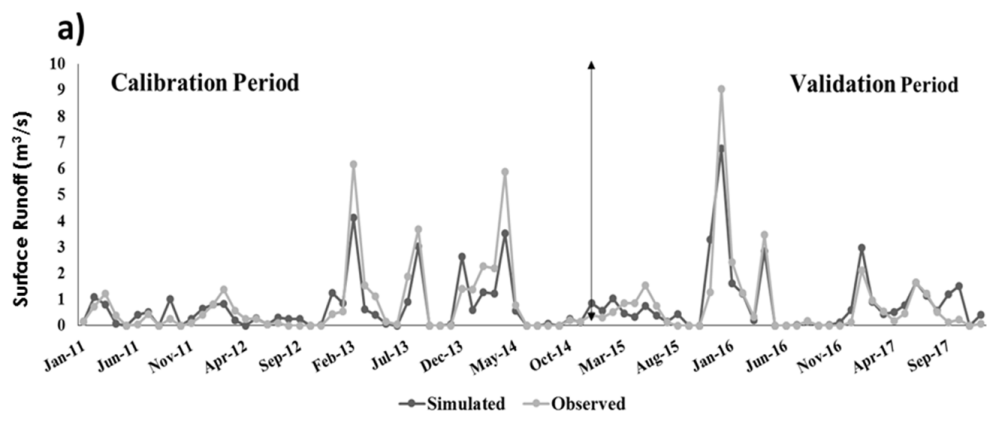

b)

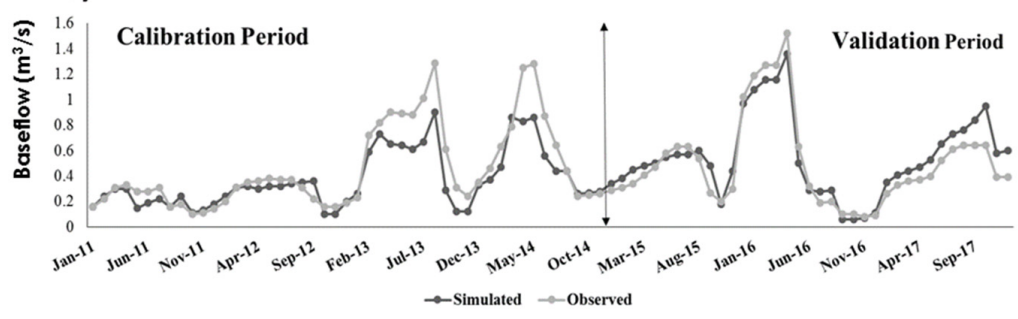

c)

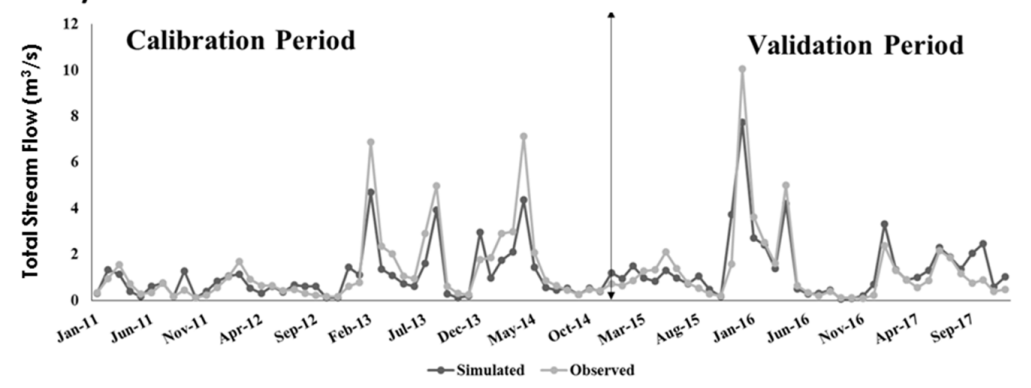

Figure 5. Observed and SWAT-simulated average monthly (a) surface runoff $\left(\mathrm{m}^{3} / \mathrm{s}\right),(\mathbf{b})$ baseflows $\left(\mathrm{m}^{3} / \mathrm{s}\right)$, and (c) total flow $\left(\mathrm{m}^{3} / \mathrm{s}\right)$ rates for the calibration (January 2011-December 2014) and validation periods (January 2015-December 2017). 


\subsection{Prioritizing Subwatersheds for BMPs}

Average annual values (2011-2017) of surface runoff $\left(\mathrm{mm} \mathrm{ha}^{-1}\right.$ year $\left.{ }^{-1}\right)$ estimated using the SWAT model are shown in Figure 6. The values of average annual surface runoff varied from $2.3 \mathrm{~mm} \mathrm{ha}^{-1}$ year $^{-1}$ to $11,980 \mathrm{~mm} \mathrm{ha}^{-1}$ year $^{-1}$. Generally, the subwatersheds (Figure 6) dominated by urban areas generated high surface runoff. As stated earlier in the manuscript, the SWAT model was not calibrated for sediment, since no observed data for sediment was available for this watershed. Therefore, sediment yield results available from the SWAT model were not considered for this study. However, the relationship between surface runoff and the sediment yield has been well documented [86]. With increases in surface runoff, sediment yield from upland areas increases [87].

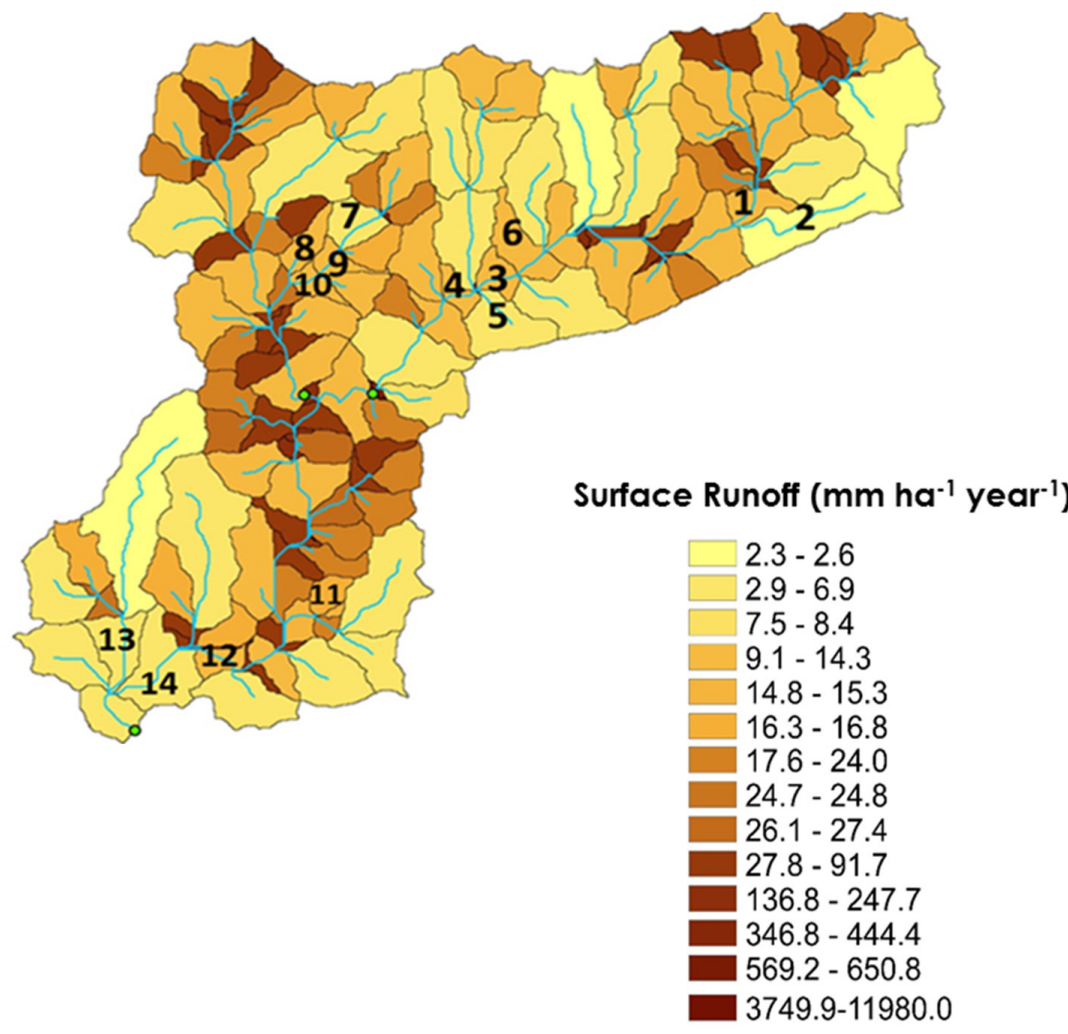

Figure 6. Average annual surface runoff $\left(\mathrm{mm} \mathrm{ha}^{-1}\right.$ year $\left.^{-1}\right)$ generated in each subwatershed.

\subsection{Land Use Change Scenario}

The calibrated SWAT model was used to simulate the average annual surface runoff under the land use change scenario for the period from January 2011 to December 2017. It was observed that the subwatersheds (labelled in Figure 6) that had a higher percentage of forested area (threshold of $50 \%$ ) before the land use change scenario showed an increase in the simulated surface runoff after the land use change scenario (Table 10). Therefore, the greater amounts of surface runoff generated from these subwatersheds would increase sediment yield from uplands.

Overall, since the upland sites (construction sites) were the dominant sources of suspended sediment in this watershed, BMPs should be targeted at construction sites in the subwatersheds generating disproportionately high amounts of surface runoff. Overall, the results of this study show that combining watershed level modeling and the use of sediment fingerprinting techniques can help in targeting BMPs effectively. The quantity of sediment discharged from construction sites can be minimized by using BMPs such as silt fences, detention basins, utilization of gravel bags around drainage inlets, vegetative filter strips, bioretention areas, and constructed wetlands. Riparian buffer systems should be properly managed, as these systems are effective at reducing sediment delivery to streams. 
Table 10. Change in the surface runoff $\left(\mathrm{mm} \mathrm{ha}^{-1} \mathrm{year}^{-1}\right)$ from subwatersheds with the land use change scenario.

\begin{tabular}{|c|c|c|c|c|c|c|}
\hline \multirow[b]{2}{*}{ Subwatershed } & \multicolumn{3}{|c|}{ Before Land Use Change } & \multicolumn{3}{|c|}{ After Land Use Change } \\
\hline & $\begin{array}{c}\text { Forested } \\
\%\end{array}$ & $\begin{array}{c}\text { Urban } \\
\%\end{array}$ & $\begin{array}{c}\text { Surface Runoff } \\
\left(\mathrm{mm} \mathrm{ha}^{-1} \text { year }^{-1}\right)\end{array}$ & $\begin{array}{c}\text { Forested } \\
\%\end{array}$ & $\begin{array}{c}\text { Urban } \\
\%\end{array}$ & $\begin{array}{c}\text { Surface Runoff } \\
\left(\mathrm{mm} \mathrm{ha}^{-1} \text { year }^{-1}\right)\end{array}$ \\
\hline 1 & 50.6 & 18.3 & 12.8 & 0 & 68.9 & 29.8 \\
\hline 2 & 62.2 & 7.3 & 2.3 & 0 & 69.5 & 7.5 \\
\hline 3 & 84.3 & 8.6 & 10.0 & 0 & 92.9 & 39.6 \\
\hline 4 & 91.4 & 7.2 & 14.1 & 0 & 98.7 & 57.0 \\
\hline 5 & 74.7 & 15.3 & 4.6 & 0 & 90 & 14.5 \\
\hline 6 & 70.2 & 13.7 & 9.6 & 0 & 83.9 & 16.5 \\
\hline 7 & 67.6 & 11 & 6.4 & 0 & 78.6 & 23.0 \\
\hline 8 & 75.1 & 23.5 & 9.3 & 0 & 98.6 & 34.1 \\
\hline 9 & 76.2 & 15.9 & 11.0 & 0 & 92.1 & 45.7 \\
\hline 10 & 96 & 0.7 & 10.7 & 0 & 96.6 & 55.6 \\
\hline 11 & 68.3 & 11.2 & 16.3 & 0 & 79.5 & 46.5 \\
\hline 12 & 87.2 & 5.2 & 12.2 & 0 & 92.4 & 46.9 \\
\hline 13 & 89.4 & 3.9 & 4.6 & 0 & 93.2 & 19.9 \\
\hline 14 & 82.9 & 11.8 & 3.3 & 0 & 94.8 & 11.8 \\
\hline
\end{tabular}

\section{Conclusions}

The application of sediment fingerprinting in the Moore's Mill Creek watershed provided important information on the relative contributions from construction sites and stream banks to suspended sediment. The results of this study show that construction sites were generally the dominant sources of suspended sediment within this watershed for both the particle size fractions. The rapid urbanization in this watershed has increased the amount of surface runoff generated within this watershed, which has resulted in the greater entrainment of sediment from construction sites in the runoff and hence greater sediment delivery into the waterways. To minimize the sediment delivery to streams in this watershed, BMPs (e.g., silt fences, detention basins, vegetative filter strips) should be targeted in subwatersheds that contain construction sites and generate disproportionately high amounts of surface runoff. The conjunctive use of the SWAT model and the sediment fingerprinting procedure provided two different but compatible approaches to understanding the sediment erosion processes and developing an approach to target BMPs effectively in this urbanized watershed.

Author Contributions: Conceptualization, K.M., J.L. and P.S.; Methodology, K.M. and J.L.; Formal Analysis, K.M.; Resources, J.L., S.S.; Writing-Original Draft Preparation, K.M.; Writing-Review \& Editing, K.M., J.L., P.S. and S.S.; Project Administration, J.L.; Supervision, J.L.

Funding: Funding for this project was provided by the U.S. Geological Survey (USGS) State Water Resources Competitive Grants Program (Project No. 2016AL176B) and Auburn University Intramural Grant Program.

Acknowledgments: We thank staff at the City of Auburn's Watershed Division and Moore's Mill Club, Auburn, AL for their assistance in this study.

Conflicts of Interest: The authors declare no conflict of interest.

\section{References}

1. Davis, C.M.; Fox, J.F. Sediment Fingerprinting: Review of the Method and Future Improvements for Allocating Nonpoint Source Pollution. J. Environ. Eng. 2009, 135, 490-504. [CrossRef]

2. Harbor, J. Engineering geomorphology at the cutting edge of land disturbance: Erosion and sediment control on construction sites. Geomorphology 1999, 31, 247-263. [CrossRef]

3. Luijendijk, A.; Hagenaars, G.; Ranasinghe, R.; Baart, F.; Donchyts, G.; Aarninkhof, S. The State of the World's Beaches. Sci. Rep. 2018, 8, 6641. [CrossRef] [PubMed]

4. Czuba, J.A.; Magirl, C.S.; Czuba, C.R.; Grossman, E.E.; Curran, C.A.; Gendaszek, A.S.; Dinicola, R.S. Sediment load from major rivers into Puget Sound and its adjacent waters: U.S. Geological Survey Fact Sheet 2011-3083. USGS: Reston, VA, USA, 2011.

5. Kemp, P.; Sear, D.; Collins, A.; Naden, P.; Jones, I. The impacts of fine sediment on riverine fish. Hydrol. Process. 2011, 25, 1800-1821. [CrossRef] 
6. Vercruysse, K.; Grabowski, R.C.; Rickson, R.J. Suspended sediment transport dynamics in rivers: Multi-scale drivers of temporal variation. Earth-Sci. Rev. 2017, 166, 38-52. [CrossRef]

7. Koiter, A.J.; Lobb, D.A.; Owens, P.N.; Petticrew, E.L.; Tiessen, K.H.D.; Li, S. Investigating the role of connectivity and scale in assessing the sources of sediment in an agricultural watershed in the Canadian prairies using sediment source fingerprinting. J. Soils Sediments 2013, 13, 1676-1691. [CrossRef]

8. US EPA. USEPA National Summary of State Information I Water Quality Assessment and TMDL Information. Available online: https://ofmpub.epa.gov/waters10/attains_nation_cy.control\#STREAM/CREEK/RIVER (accessed on 18 September 2018).

9. McCarney-Castle, K.; Childress, T.M.; Heaton, C.R. Sediment source identification and load prediction in a mixed-use Piedmont watershed, South Carolina. J. Environ. Manag. 2017, 185, 60-69. [CrossRef] [PubMed]

10. Mukundan, R.; Radcliffe, D.E.; Ritchie, J.C.; Risse, L.M.; McKinley, R.A. Sediment Fingerprinting to Determine the Source of Suspended Sediment in a Southern Piedmont Stream. J. Environ. Qual. 2010, 39, 1328-1337. [CrossRef] [PubMed]

11. The World Bank World Bank Open Data: Urban Population (\% of Total) and Urban Population Growth (Annual \%). Available online: https://data.worldbank.org/indicator/SP.POP.GROW and https://data. worldbank.org/indicator/SP.URB.TOTL.IN.ZS (accessed on 31 October 2018).

12. Russell, K.L.; Vietz, G.J.; Fletcher, T.D. Global sediment yields from urban and urbanizing watersheds. Earth-Sci. Rev. 2017, 168, 73-80. [CrossRef]

13. Walsh, C.J.; Fletcher, T.D.; Ladson, A.R. Stream restoration in urban catchments through redesigning stormwater systems: Looking to the catchment to save the stream. J. N. Am. Benthol. Soc. 2005, 24, 690-705. [CrossRef]

14. Rossi, L.; Chèvre, N.; Fankhauser, R.; Margot, J.; Curdy, R.; Babut, M.; Barry, D.A. Sediment contamination assessment in urban areas based on total suspended solids. Water Res. 2013, 47, 339-350. [CrossRef] [PubMed]

15. Fang, X.; Zech, W.C.; Logan, C.P. Stormwater Field Evaluation and Its Challenges of a Sediment Basin with Skimmer and Baffles at a Highway Construction Site. Water 2015, 7, 3407-3430. [CrossRef]

16. Anderson, C.J.; Lockaby, B.G. The Effectiveness of Forestry Best Management Practices for Sediment Control in the Southeastern United States: A Literature Review. South. J. Appl. For. 2011, 35, 170-177. [CrossRef]

17. Arabi, M.; Govindaraju, R.S.; Hantush, M.M.; Engel, B.A. Role of Watershed Subdivision on Modeling the Effectiveness of Best Management Practices with Swat1. JAWRA J. Am. Water Resour. Assoc. 2006, 42, 513-528. [CrossRef]

18. Kaspar, T.C.; Radke, J.K.; Laflen, J.M. Small grain cover crops and wheel traffic effects on infiltration, runoff, and erosion. J. Soil Water Conserv. 2001, 56, 160-164.

19. Panagos, P.; Borrelli, P.; Meusburger, K.; van der Zanden, E.H.; Poesen, J.; Alewell, C. Modelling the effect of support practices (P-factor) on the reduction of soil erosion by water at European scale. Environ. Sci. Policy 2015, 51, 23-34. [CrossRef]

20. Walling, D.E. Tracing suspended sediment sources in catchments and river systems. Sci. Total Environ. 2005, 344, 159-184. [CrossRef] [PubMed]

21. Collins, A.L.; Pulley, S.; Foster, I.D.L.; Gellis, A.; Porto, P.; Horowitz, A.J. Sediment source fingerprinting as an aid to catchment management: A review of the current state of knowledge and a methodological decision-tree for end-users. J. Environ. Manag. 2017, 194, 86-108. [CrossRef] [PubMed]

22. Barthod, L.R.M.; Liu, K.; Lobb, D.A.; Owens, P.N.; Martínez-Carreras, N.; Koiter, A.J.; Petticrew, E.L.; McCullough, G.K.; Liu, C.; Gaspar, L. Selecting Color-based Tracers and Classifying Sediment Sources in the Assessment of Sediment Dynamics Using Sediment Source Fingerprinting. J. Environ. Qual. 2015, 44, 1605-1616. [CrossRef] [PubMed]

23. Liu, K.; Lobb, D.A.; Miller, J.J.; Owens, P.N.; Caron, M.E.G. Determining sources of fine-grained sediment for a reach of the Lower Little Bow River, Alberta, using a colour-based sediment fingerprinting approach. Can. J. Soil Sci. 2017, 98, 55-69. [CrossRef]

24. Nosrati, K.; Govers, G.; Semmens, B.X.; Ward, E.J. A mixing model to incorporate uncertainty in sediment fingerprinting. Geoderma 2014, 217-218, 173-180. [CrossRef]

25. Collins, A.L.; Walling, D.E. Selecting fingerprint properties for discriminating potential suspended sediment sources in river basins. J. Hydrol. 2002, 261, 218-244. [CrossRef] 
26. Smith, H.G.; Blake, W.H. Sediment fingerprinting in agricultural catchments: A critical re-examination of source discrimination and data corrections. Geomorphology 2014, 204, 177-191. [CrossRef]

27. Koiter, A.J.; Owens, P.N.; Petticrew, E.L.; Lobb, D.A. The role of gravel channel beds on the particle size and organic matter selectivity of transported fine-grained sediment: Implications for sediment fingerprinting and biogeochemical flux research. J. Soils Sediments 2015, 15, 2174-2188. [CrossRef]

28. Huisman, N.L.H.; Karthikeyan, K.G.; Lamba, J.; Thompson, A.M.; Peaslee, G. Quantification of seasonal sediment and phosphorus transport dynamics in an agricultural watershed using radiometric fingerprinting techniques. J. Soils Sediments 2013, 13, 1724-1734. [CrossRef]

29. Wilson, C.G.; Kuhnle, R.A.; Bosch, D.D.; Steiner, J.L.; Starks, P.J.; Tomer, M.D.; Wilson, G.V. Quantifying relative contributions from sediment sources in Conservation Effects Assessment Project watersheds. J. Soil Water Conserv. 2008, 63, 523-532. [CrossRef]

30. Miller, J.R.; Lord, M.; Yurkovich, S.; Mackin, G.; Kolenbrander, L. Historical trends in sedimentation rates and sediment provenance, fairfield lake, western north carolina1. JAWRA J. Am. Water Resour. Assoc. 2005, 41, 1053-1075. [CrossRef]

31. Mzuza, M.K.; Weiguo, Z.; Chapola, L.S.; Tembo, M.; Kapute, F. Determining sources of sediments at Nkula Dam in the Middle Shire River, Malawi, using mineral magnetic approach. J. Afr. Earth Sci. 2017, 126, $23-32$. [CrossRef]

32. Walling, D.E.; Owens, P.N.; Leeks, G.J.L. Fingerprinting suspended sediment sources in the catchment of the River Ouse, Yorkshire, UK. Hydrol. Process. 1999, 13, 955-975. [CrossRef]

33. Martínez-Carreras, N.; Krein, A.; Gallart, F.; Iffly, J.F.; Pfister, L.; Hoffmann, L.; Owens, P.N. Assessment of different colour parameters for discriminating potential suspended sediment sources and provenance: A multi-scale study in Luxembourg. Geomorphology 2010, 118, 118-129. [CrossRef]

34. Fox, J.F.; Papanicolaou, A.N. The Use of Carbon and Nitrogen Isotopes to Study Watershed Erosion Processes1. JAWRA J. Am. Water Resour. Assoc. 2007, 43, 1047-1064. [CrossRef]

35. Rhoton, F.E.; Emmerich, W.E.; DiCarlo, D.A.; McChesney, D.S.; Nearing, M.A.; Ritchie, J.C. Identification of Suspended Sediment Sources Using Soil Characteristics in a Semiarid Watershed. Soil Sci. Soc. Am. J. 2008, 72, 1102. [CrossRef]

36. Fu, B.; Field, J.B.; Newham, L.T. Tracing the source of sediment in Australian coastal catchments. In Regolith 2006-Consolidation and Dispersion of Ideas; CRC LEME: Perth, Australian, 2006.

37. Pulley, S.; Foster, I.; Antunes, P. The uncertainties associated with sediment fingerprinting suspended and recently deposited fluvial sediment in the Nene river basin. Geomorphology 2015, 228, 303-319. [CrossRef]

38. Palazón, L.; Gaspar, L.; Latorre, B.; Blake, W.H.; Navas, A. Identifying sediment sources by applying a fingerprinting mixing model in a Pyrenean drainage catchment. J. Soils Sediments 2015, 15, 2067-2085. [CrossRef]

39. Wilkinson, S.N.; Hancock, G.J.; Bartley, R.; Hawdon, A.A.; Keen, R.J. Using sediment tracing to assess processes and spatial patterns of erosion in grazed rangelands, Burdekin River basin, Australia. Agric. Ecosyst. Environ. 2013, 180, 90-102. [CrossRef]

40. Pulley, S.; Foster, I.; Collins, A.L. The impact of catchment source group classification on the accuracy of sediment fingerprinting outputs. J. Environ. Manag. 2017, 194, 16-26. [CrossRef] [PubMed]

41. Collins, A.L.; Walling, D.E.; Webb, L.; King, P. Apportioning catchment scale sediment sources using a modified composite fingerprinting technique incorporating property weightings and prior information. Geoderma 2010, 155, 249-261. [CrossRef]

42. Foucher, A.; Laceby, P.J.; Salvador-Blanes, S.; Evrard, O.; Le Gall, M.; Lefèvre, I.; Cerdan, O.; Rajkumar, V.; Desmet, M. Quantifying the dominant sources of sediment in a drained lowland agricultural catchment: The application of a thorium-based particle size correction in sediment fingerprinting. Geomorphology 2015, 250, 271-281. [CrossRef]

43. Devereux, O.H.; Prestegaard, K.L.; Needelman, B.A.; Gellis, A.C. Suspended-sediment sources in an urban watershed, Northeast Branch Anacostia River, Maryland. Hydrol. Process. 2010, 24, 1391-1403. [CrossRef]

44. Franz, C.; Makeschin, F.; Weiß, H.; Lorz, C. Sediments in urban river basins: Identification of sediment sources within the Lago Paranoá catchment, Brasilia DF, Brazil-Using the fingerprint approach. Sci. Total Environ. 2014, 466-467, 513-523. [CrossRef] [PubMed] 
45. Laceby, J.P.; Evrard, O.; Smith, H.G.; Blake, W.H.; Olley, J.M.; Minella, J.P.G.; Owens, P.N. The challenges and opportunities of addressing particle size effects in sediment source fingerprinting: A review. Earth-Sci. Rev. 2017, 169, 85-103. [CrossRef]

46. Owens, P.N.; Koiter, A.; Petticrew, E.L.; Lobb, D.A. The preferential transport of sediment and its implications for sediment fingerprinting: A flume simulation. In Proceedings of the EGU General Assembly Conference Abstracts, Vienna, Austria, 12-17 April 2015; Volume 17.

47. Deasy, C.; Brazier, R.E.; Heathwaite, A.L.; Hodgkinson, R. Pathways of runoff and sediment transfer in small agricultural catchments. Hydrol. Process. Int. J. 2009, 23, 1349-1358. [CrossRef]

48. Chanasyk, D.S.; Mapfumo, E.; Willms, W. Quantification and simulation of surface runoff from fescue grassland watersheds. Agric. Water Manag. 2003, 59, 137-153. [CrossRef]

49. Easton, Z.M.; Fuka, D.R.; Walter, M.T.; Cowan, D.M.; Schneiderman, E.M.; Steenhuis, T.S. Re-conceptualizing the soil and water assessment tool (SWAT) model to predict runoff from variable source areas. J. Hydrol. 2008, 348, 279-291. [CrossRef]

50. Rostamian, R.; Jaleh, A.; Afyuni, M.; Mousavi, S.F.; Heidarpour, M.; Jalalian, A.; Abbaspour, K.C. Application of a SWAT model for estimating runoff and sediment in two mountainous basins in central Iran. Hydrol. Sci. J. 2008, 53, 977-988. [CrossRef]

51. Palazón, L.; Latorre, B.; Gaspar, L.; Blake, W.H.; Smith, H.G.; Navas, A. Combining catchment modelling and sediment fingerprinting to assess sediment dynamics in a Spanish Pyrenean river system. Sci. Total Environ. 2016, 569, 1136-1148. [CrossRef] [PubMed]

52. Palazón, L.; Gaspar, L.; Latorre, B.; Blake, W.H.; Navas, A. Evaluating the importance of surface soil contributions to reservoir sediment in alpine environments: A combined modelling and fingerprinting approach in the Posets-Maladeta Natural Park. Solid Earth 2014, 5, 963-978. [CrossRef]

53. ADEM Alabama 303 (d) list 2016. 2016. Available online: http://adem.alabama.gov/programs/water/ wquality/2016AL303dList.pdf (accessed on 30 August 2016).

54. City of Auburn The comprehensive plan for the city of auburn 2011. 2011. Available online: https:/ / www.auburnalabama.org/CompPlan2030/4.0\%20Natural\%20Systems\%20-Final.pdf (accessed on 31 October 2018).

55. Phillips, J.M.; Russell, M.A.; Walling, D.E. Time-integrated sampling of fluvial suspended sediment: A simple methodology for small catchments. Hydrol. Process. 2000, 14, 2589-2602. [CrossRef]

56. Walling, D.E.; Collins, A.L.; Stroud, R.W. Tracing suspended sediment and particulate phosphorus sources in catchments. J. Hydrol. 2008, 350, 274-289. [CrossRef]

57. Lamba, J.; Karthikeyan, K.G.; Thompson, A.M. Apportionment of suspended sediment sources in an agricultural watershed using sediment fingerprinting. Geoderma 2015, 239-240, 25-33. [CrossRef]

58. USEPA. Microwave Assisted Acid Digestion of Siliceous and Organically Based Matrices; OHW, Method 3052; USEPA: Washington, DC, USA, 1996.

59. Gellis, A.C.; Noe, G.B. Sediment source analysis in the Linganore Creek watershed, Maryland, USA, using the sediment fingerprinting approach: 2008 to 2010. J. Soils Sediments 2013, 13, 1735-1753. [CrossRef]

60. Kraushaar, S.; Schumann, T.; Ollesch, G.; Schubert, M.; Vogel, H.-J.; Siebert, C. Sediment fingerprinting in northern Jordan: Element-specific correction factors in a carbonatic setting. J. Soils Sediments 2015, 15, 2155-2173. [CrossRef]

61. Collins, A.L.; Walling, D.E.; Leeks, G.J.L. Source type ascription for fluvial suspended sediment based on a quantitative composite fingerprinting technique. Catena 1997, 29, 1-27. [CrossRef]

62. Yu, M.; Rhoads, B.L. Floodplains as a source of fine sediment in grazed landscapes: Tracing the source of suspended sediment in the headwaters of an intensively managed agricultural landscape. Geomorphology 2018. [CrossRef]

63. Carter, J.; Owens, P.N.; Walling, D.E.; Leeks, G.J.L. Fingerprinting suspended sediment sources in a large urban river system. Sci. Total Environ. 2003, 314-316, 513-534. [CrossRef]

64. Nachar, N. The Mann-Whitney U: A Test for Assessing Whether Two Independent Samples Come from the Same Distribution. Tutor. Quant. Methods Psychol. 2008, 4, 13-20. [CrossRef]

65. Collins, A.L.; Zhang, Y.; McChesney, D.; Walling, D.E.; Haley, S.M.; Smith, P. Sediment source tracing in a lowland agricultural catchment in southern England using a modified procedure combining statistical analysis and numerical modelling. Sci. Total Environ. 2012, 414, 301-317. [CrossRef] [PubMed] 
66. Liu, B.; Storm, D.E.; Zhang, X.J.; Cao, W.; Duan, X. A new method for fingerprinting sediment source contributions using distances from discriminant function analysis. Catena 2016, 147, 32-39. [CrossRef]

67. Douglas-Mankin, K.R.; Srinivasan, R.; Arnold, J.G. Soil and Water Assessment Tool (SWAT) model: Current developments and applications. Trans. ASABE 2010, 53, 1423-1431. [CrossRef]

68. Neitsch, S.L.; Arnold, J.G.; Kiniry, J.R.; Williams, J.R. Soil \& Water Assessment Tool_Theoretical Documentation Version 2009; Technical Report; Texas A\&M University: Temple, TX, USA, 2009. Available online: http: / / swat.tamu.edu/documentation/ (accessed on 31 October 2018).

69. Mishra, S.K.; Singh, V.P. SCS-CN Method. In Soil Conservation Service Curve Number (SCS-CN) Methodology; Water Science and Technology Library; Springer: Dordrecht, The Netherlands, 2003; pp. 84-146, ISBN 978-90-481-6225-3.

70. Hargreaves, G.H.; Zohrab, A. Samani Reference Crop Evapotranspiration from Temperature. Appl. Eng. Agric. 1985, 1, 96-99. [CrossRef]

71. Lim, K.J.; Engel, B.A.; Tang, Z.; Choi, J.; Kim, K.-S.; Muthukrishnan, S.; Tripathy, D. Automated Web GIS Based Hydrograph Analysis Tool, WHAT 1. JAWRA J. Am. Water Resour. Assoc. 2005, 41, 1407-1416. [CrossRef]

72. Moriasi, D.N.; Arnold, J.G.; Liew, M.W.V.; Bingner, R.L.; Harmel, R.D.; Veith, T.L. Model Evaluation Guidelines for Systematic Quantification of Accuracy in Watershed Simulations. Trans. ASABE 2007, 50, 885-900. [CrossRef]

73. Bini, C.; Sartori, G.; Wahsha, M.; Fontana, S. Background levels of trace elements and soil geochemistry at regional level in NE Italy. J. Geochem. Explor. 2011, 109, 125-133. [CrossRef]

74. Cepel, M.; Nikel, G. Nickel: A review of its sources and environmental toxicology. Pol. J. Environ. Stud. 2006, 15, 375-382.

75. Iyaka, Y.A. Nickel in soils: A review of its distribution and impacts. Sci. Res. Essays 2011, 6, 6774-6777.

76. Hooda, P. Trace Elements in Soils; John Wiley \& Sons: Chippenham, Wiltshire, UK, 2010; ISBN 978-1-4443-1948-4.

77. Cheng, $\mathrm{H}$; $\mathrm{Hu}, \mathrm{Y}$. Lead $(\mathrm{Pb})$ isotopic fingerprinting and its applications in lead pollution studies in China: A review. Environ. Pollut. 2010, 158, 1134-1146. [CrossRef] [PubMed]

78. Tyler, G. Rare earth elements in soil and plant systems-A review. Plant Soil 2004, 267, 191-206. [CrossRef]

79. Bledsoe, B.P.; Watson, C.C. Effects of Urbanization on Channel Instability1. JAWRA J. Am. Water Resour. Assoc. 2001, 37, 255-270. [CrossRef]

80. Bosa, S.; Petti, M.; Pascolo, S.; Bosa, S.; Petti, M.; Pascolo, S. Numerical Modelling of Cohesive Bank Migration. Water 2018, 10, 961. [CrossRef]

81. Ferrel, K.R.A.; Patsinghasanee, S.; Kimura, I.; Shimizu, Y. Coupled Model of Bank Erosion and Meander Evolution for Cohesive Riverbanks. Available online: https:/ /www.mdpi.com/2076-3263/8/10/359/htm (accessed on 6 October 2018).

82. Liu, X.; Zhang, X.; Zhang, M. Major Factors Influencing the Efficacy of Vegetated Buffers on Sediment Trapping: A Review and Analysis. J. Environ. Qual. 2008, 37, 1667. [CrossRef] [PubMed]

83. Osman, A.M.; Thorne, C.R. Riverbank stability analysis. I: Theory. J. Hydraul. Eng. 1988, 114, $134-150$. [CrossRef]

84. Pitt, R.; Clark, S.E.; Lake, D.W. Construction Site Erosion and Sediment Controls: Planning, Design and Performance; DEStech Publications, Inc.: Lancaster, PA, USA, 2007; ISBN 978-1-932078-38-1.

85. Malhotra, K.; Lamba, J.; Shepherd, S. Sediment fingerprinting to identify sources of stream bed sediment in an urbanized watershed. In 2018 ASABE Annual International Meeting; ASABE Paper No. 1801826; ASABE: Detroit, MI, USA, 2018; p. 1.

86. Schmalz, B.; Zhang, Q.; Kuemmerlen, M.; Cai, Q.; Jähnig, S.C.; Fohrer, N. Modelling spatial distribution of surface runoff and sediment yield in a Chinese river basin without continuous sediment monitoring. Hydrol. Sci. J. 2015, 1-24. [CrossRef]

87. Gholami, L.; Sadeghi, S.H.; Homaee, M. Straw Mulching Effect on Splash Erosion, Runoff, and Sediment Yield from Eroded Plots. Soil Sci. Soc. Am. J. 2013, 77, 268-278. [CrossRef] 